\title{
Targeting the Hemopexin-like Domain of Latent Matrix Metalloproteinase-9 (proMMP-9) with a Small Molecule Inhibitor Prevents the Formation of Focal Adhesion Junctions
}

\author{
Vincent M. Alford, ${ }^{\dagger, \S ® 0 ~ A n u s h r e e ~ K a m a t h, ~}{ }^{\ddagger}$ Xiaodong Ren, ${ }^{\ddagger}$ Kunal Kumar, ${ }^{\ddagger}$ Qianwen Gan, ${ }^{\ddagger}$ Monaf Awwa, \\ Michael Tong, ${ }^{\dagger}$ Markus A. Seeliger, ${ }^{\dagger, \|}$ Jian Cao, ${ }^{\S}$ Iwao Ojima, ${ }^{\ddagger}, \|_{\odot}$ and Nicole S. Sampson ${ }^{*},, \|_{\odot}$ \\ ${ }^{\dagger}$ Department of Molecular and Cellular Pharmacology, Stony Brook University, Stony Brook, New York, United States \\ ${ }^{\ddagger}$ Department of Chemistry, Stony Brook University, Stony Brook, New York, United States \\ ${ }^{\S}$ Department of Medicine, Stony Brook University, Stony Brook, New York, United States \\ "Institute of Chemical Biology and Drug Discovery, Stony Brook, New York, United States
}

\section{Supporting Information}

ABSTRACT: A lack of target specificity has greatly hindered the success of inhibitor development against matrix metalloproteinases (MMPs) for the treatment of various cancers. The MMP catalytic domains are highly conserved, whereas the hemopexin-like domains of MMPs are unique to each family member. The hemopexin-like domain of MMP-9 enhances cancer cell migration through self-interaction and heterointeractions with cell surface proteins including CD44 and $\alpha 4 \beta 1$ integrin. These interactions activate EGFR-MAP kinase dependent signaling that leads to cell migration. In this work, we generated a library of compounds, based on hit molecule $N$-[4-(difluoromethoxy)phenyl]-2-[(4-oxo-6-propyl-1H-pyrimidin-2-yl)sulfanyl]-acetamide, that target the hemopexin-like domain of MMP-9. We identify $\mathrm{N}$-(4-fluorophenyl)-4-(4-oxo-3,4,5,6,7,8-hexahydroquinazolin-2-ylthio)butanamide, 3c, as a potent lead $\left(K_{\mathrm{d}}=320 \mathrm{nM}\right)$ that is specific for binding to the proMMP-9 hemopexin-like domain. We demonstrate that 3c disruption of MMP-9 homodimerization prevents association of proMMP-9 with both $\alpha 4 \beta 1$ integrin and CD44 and results in the dissociation of EGFR. This disruption results in decreased phosphorylation of Src and its downstream target proteins focal adhesion kinase (FAK) and paxillin (PAX), which are implicated in promoting tumor cell growth, migration, and invasion. Using a chicken chorioallantoic membrane in vivo assay, we demonstrate that $500 \mathrm{nM} 3 \mathrm{c}$ blocks cancer cell invasion of the basement membrane and reduces angiogenesis. In conclusion, we present a mechanism of action for $3 \mathrm{c}$ whereby targeting the hemopexin domain results in decreased cancer cell migration through simultaneous disruption of $\alpha 4 \beta 1$ integrin and EGFR signaling pathways, thereby preventing signaling bypass. Targeting through the hemopexin-like domain is a powerful approach to antimetastatic drug development.
M etastasis accounts for $90 \%$ of all human cancer related deaths, yet we lack adequate drugs to target this biological process often associated with aggressive cancers. ${ }^{1}$ Accumulating evidence suggests an important role for matrix metalloproteinases (MMPs) in promoting cancer progression whereby they modify their surrounding environment to promote the growth and spread of tumor cells. ${ }^{2-5}$ Although MMPs represent the most prominent family of proteinases associated with tumorigenesis, drugs designed to inhibit their proteolytic activities largely failed in clinical trials due to issues with selectivity for individual MMPs. ${ }^{6}$ The highly conserved catalytic domain within this family of zymogens required a paradigm shift to the development of novel MMP inhibitors (MMPIs) targeting less conserved, noncatalytic functional domain(s) of the proteases to increase target specificity and selectivity.?

The biological functions of MMPs extend beyond just their proteolytic function and include induction of complex signaling cascades. $^{8-10}$ Homodimerization of secreted proMMP-9 hemopexin domains is sufficient to induce cancer cell migration independent of proteolytic activity. ${ }^{11}$ Using an shRNA approach, the mechanism behind this phenotype was dissected and found to be dependent on an interaction between MMP-9 and CD44 at the cell surface. This interaction required an intact MMP-9 hemopexin domain (PEX-9). Interaction between CD44 and PEX-9 results in increased epidermal growth factor receptor (EGFR) phosphorylation and subsequent activation of mitogen-activated protein kinase (MAPK)/extracellular signalregulated kinases (ERK) signaling, thereby enhancing the migratory capacity of proMMP-9 expressing cancer cells. ${ }^{12}$

Received: August 29, 2017

Accepted: September 25, 2017

Published: September 25, 2017 
Scheme 1. Synthesis of Inhibitors ${ }^{a}$<smiles>[Y7]NC(=O)CSc1nc(=O)cc(CCC)[nH]1</smiles>

c:

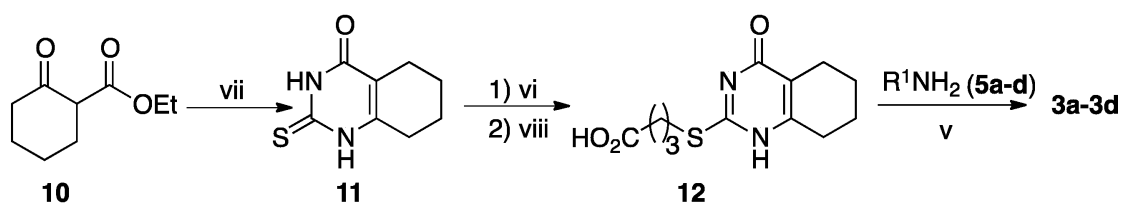

e:

d:<smiles></smiles><smiles>CCCc1cc(=O)nc(SCC(=O)N(C)c2ccccc2)[nH]1</smiles>

10<smiles>O=c1[nH]c(S)nc2ccc(I)cc12</smiles>

13

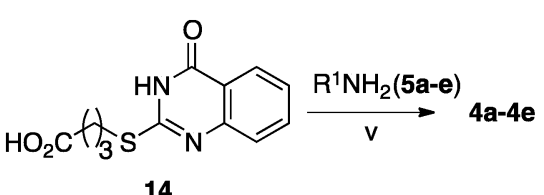

14

${ }^{a}$ Reagents and conditions. (i) 2-Bromoacetic acid, EDC. $\mathrm{HCl}$, DCM, room temp., $24 \mathrm{~h}: 67 \%$ for $6 \mathrm{a}, 47 \%$ for $\mathbf{6 c}, 28 \%$ for $\mathbf{6 b}$. (ii) $\mathrm{NaOH}, \mathrm{H}_{2} \mathrm{O}, \mathrm{THF}, 70$ ${ }^{\circ} \mathrm{C}, 2 \mathrm{~h}$ : $63 \%$ for $1 \mathrm{a}, 35 \%$ for $\mathbf{1 b}$, and $69 \%$ for 1c. (iii) Ethyl 2-bromoacetate, $\mathrm{K}_{2} \mathrm{CO}_{3}, \mathrm{MeOH}, \mathrm{H}_{2} \mathrm{O}$, rt, 15 min, $67 \%$. (iv) $\mathrm{LiOH}, \mathrm{MeOH}, \mathrm{H}_{2} \mathrm{O}, \mathrm{rt}, 2$ days, $28 \%$ for $\mathbf{8 ,} 66 \%$ for 9. (v, a) EDC.HCl, DMAP, room temp., $24 \mathrm{~h}$ : $40 \%$ for $1 \mathrm{~d}, 41 \%$ for $2 \mathrm{a}, 39 \%$ for $\mathbf{2 c}$, $52 \%$ for $3 \mathrm{a}, 46 \%$ for $3 \mathrm{~b}$, $70 \%$ for $3 \mathrm{c}, 22 \%$ for $3 \mathrm{~d}, 36 \%$ for $\mathbf{4 b}, 46 \%$ for $4 \mathbf{c}, 42 \%$ for $4 \mathrm{a}, 26 \%$ for $4 \mathrm{~d}$; (b) CDI, room temp., $24 \mathrm{~h}, 45 \%$ for $4 \mathrm{e}$. (vi) Methyl 4 -bromobutanoate, $\mathrm{K}_{2} \mathrm{CO}_{3}, \mathrm{MeOH}$, $\mathrm{H}_{2} \mathrm{O}$, reflux: $47 \%$ for 9 (overnight), 73\% for 12 (overnight), $81 \%$ for 14 (1 h). (vii) Thiourea, MeONa, MeOH, reflux, overnight, 93\%. (viii) $\mathrm{NaOH}$, EtOH, RT, overnight, 99\%. (ix) $\mathrm{LiOH}, \mathrm{DMSO}, \mathrm{H}_{2} \mathrm{O}$, room temp., 2 h, $86 \%$.

Signaling was lost upon deletion or swapping of PEX-9 with the PEX domain of its closest homologue MMP-2.

The X-ray crystal structure of the PEX domain of MMP-9 has been solved. PEX-9 forms a propeller-like structure composed of four blades, which converge and are linked between blades I and IV through disulfide bonds. ${ }^{13}$ Each blade of the PEX domain is composed of a single $\alpha$-helix and four antiparallel $\beta$-strands. They form a scaffold for substrate recognition and docking ${ }^{14}$

Published reports have shown that PEX-9 can interact with different integrin subunits to promote enhanced cancer cell migration, invasion, and survival in various cancer cell types. $^{15-20}$ Of particular interest to our study was a recent finding that peptide sequence FPGVPLDTHDVFQYREKAYFC within the central cavity of PEX9/blade IV is a binding site for $\alpha 4 \beta 1$ integrin. Treatment with synthetic peptide was found to prevent B-cell chronic lymphocytic leukemia transendothelial cell migration and survival. ${ }^{21,22}$ Mutation of either aspartic acid (Asp) residue (Asp-660 and Asp-663) in this peptide sequence abolished inhibition supporting the importance of Asp residues as key recognition sites for integrins. ${ }^{23,24}$ Furthermore, the LDT motif in this peptide sequence is a highly conserved motif found in a variety of well-known $\alpha 4 \beta 1$ integrin ligands. ${ }^{23,25,26}$

We previously utilized an in silico DOCKing approach for finding small molecules that bind to MMP-9 and identified a substituted pyrimidone, 1a, which docked to the noncatalytic PEX domain of MMP-9. ${ }^{27}$ Compound 1a inhibited proMMP9-mediated cancer cell migration and proliferation in vitro. Importantly, this compound did not inhibit MMP-9 enzymatic activity. Pyrimidone 1a specifically binds to the hemopexin domain of MMP-9 and does not bind to closely related MMPs. In addition to inhibiting proMMP9-mediated cell migration, compound 1a effectively prevented cancer metastasis in an in vivo mouse xenograft model. ${ }^{27}$

In this current study, we generated an in silico library of analogs of compound 1a to find a more potent compound for potential clinical application. After screening for optimal DOCKing scores in silico, the top 14 compounds were synthesized and tested in a 2-D collagen dot migration assay. A high nanomolar inhibitor that maintained MMP specificity was identified (compound 3c). Our data demonstrate that PEX-9 inhibitor $3 c$ selectively inhibits cell migration induced by proMMP-9, leading to reduced cell invasion predominately through disruption of $\alpha 4 \beta 1$ integrin focal adhesion complexes. Thus, PEX-9 inhibitors rectify the abnormal migratory phenotype associated with high MMP-9 expression.

\section{RESULTS}

Development of a Second Generation Hit Compound. We designed analogs of compound 1a based on possible derivative syntheses that utilized an amide and a thioether 
A

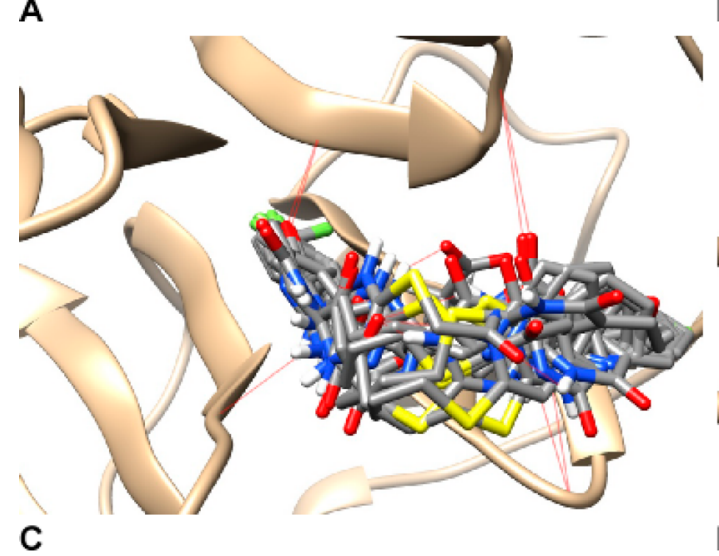

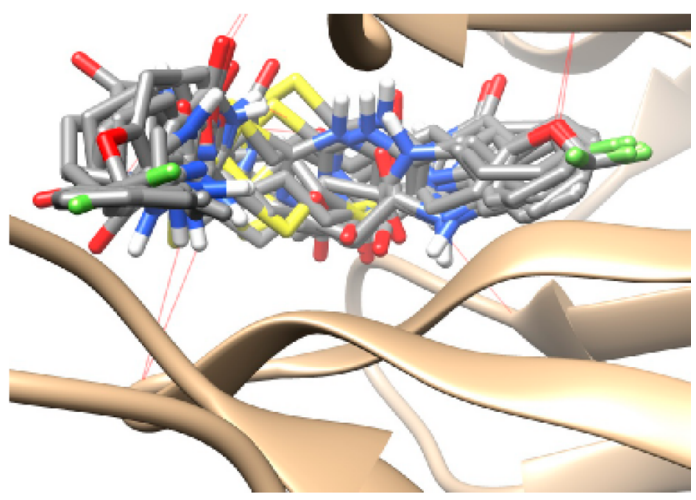

D

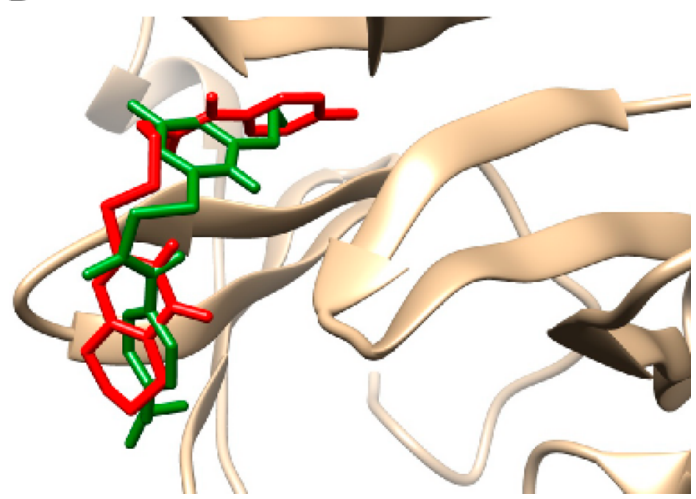

Figure 1. PEX-9 inhibitor DOCKing to PEX-9 and binding site analysis. (A,B) PEX-9 inhibitor derivatives were DOCKed within the central cavity of the hemopexin domain of PEX-9 MMP-9, and hydrogen bonding was visualized with dashed red lines. (C) A cluster of top hit compounds (2c, 3b, $3 \mathbf{c}, 3 \mathbf{a}, \mathbf{4 a}, \mathbf{4 d}$ ) was found to share a similar binding orientation. (D) The binding orientation of compound la (green) relative to compound $3 \mathrm{c}$ (red).

coupling. Thus, three moieties were varied: the amine $\left(\mathrm{R}^{1}\right)$, the linker $\left(\left[\mathrm{CH}_{2}\right]_{n}\right)$, and the sulfhydrylpyrimidone $\left(\mathrm{R}^{2}\right.$; Scheme 1$)$. To rationally prioritize the synthesis of compound 1a analogs, the University of California San Francisco (UCSF) DOCK (6.7) algorithm was used to rank various structures for predicted binding affinity. The proposed inhibitors were DOCKed to the PEX-9 domain pocket (PDB code 1ITV; Figure $1 \mathrm{~A}$ and $\mathrm{B}$ ). This pocket is at the center of the four blades of the hemopexin domain.

Among a library of 66 analogs, 14 (compounds 1a-1d, 2a, 2c, 3a-3d, 4a-4e) were chosen for synthesis based on superior DOCK algorithm scores (Scheme 1, Table S1). One motif that demonstrated consistent improvement in predicted binding affinity was modification of the 6-propylpyrimidone group to bicyclic pyrimidone systems.

Chemical Synthesis of PEX-9 Parental Compound 1a and Analogs. First, the early lead compound 1a was resynthesized to confirm the chemical structure based on full characterization, using the synthetic route shown in the Scheme 1. The synthesis commenced with the reaction of aniline 5a with bromoacetic acid in the presence of EDC. $\mathrm{HCl}$ to afford bromoacetanilide $\mathbf{6 a}$ as a white solid in $67 \%$ yield. Subsequently, 6a was reacted with thiouracil 7 in aqueous $\mathrm{NaOH}$ and heated to $70{ }^{\circ} \mathrm{C}$ for $48 \mathrm{~h}$ to give compound $\mathbf{1 a}$ in $63 \%$ yield as a white solid after recrystallization. In addition, newly designed compounds $\mathbf{1 b}$ and $\mathbf{1 c}$ were synthesized using the same synthetic process (Scheme 1).

Closely related compound $\mathbf{1 d}$ bearing a benzimidazole group was synthesized using a different route. In this synthesis, thiouracil 7 was converted to the corresponding thioacetic acid $\mathbf{8}$, followed by the amide coupling with 2 -aminobenzimidazole to give compound $\mathbf{1 d}$ in modest yield. The attempted preparation of 2-bromoacetylaminobenzimidazole, following the synthetic route for compound 1a did not yield a pure compound. Thus, we judged that the synthetic strategy which coupled $\mathrm{R}^{1}$ last would enable a better modular synthesis of analogs.

With this modular synthesis protocol in hand, we undertook synthesis of the analogs based on the original $\mathrm{R}^{1}$ moiety and two bicyclic sulfhydrylpyrimidones, as well as the linkers with different lengths and a variety of aromatic $\mathrm{R}^{2}$ substituents. Synthesis of compounds $2 \mathrm{a}$ and $2 \mathrm{c}$ followed the same strategy as that for compound $\mathbf{1 d}$ by converting 7 to the corresponding thiobutanoic acid 9, followed by amide formation by coupling with 4-substituted anilines $\mathbf{5 a}$ and $\mathbf{5 c}$ to give $\mathbf{2 a}$ and $\mathbf{2 c}$ in modest yields.

In a similar manner, compounds $\mathbf{3 a}-\mathbf{3} \mathbf{d}$ were synthesized in moderate yields through the coupling of anilines and 2aminobenzimidazole with thiobutanoic acid 12, prepared from 2-sulfhydryl-5,6,7,8-tetrahydroquinazolin-4(3H)-one (11) as shown. Compound $\mathbf{1 1}$ was readily prepared by reacting keto ester 10 with thiourea and a base. Compounds $4 a-4 e$ were synthesized in moderate yields using the same strategy except for starting from 2-sulfhydryltetrahydroquinazolinone (13) and employed anilines and 2-aminoimidazole for the amide formation.

Structure-Activity Relationship Analysis of PEX-9 Derivative Compounds. COS-1 cells were chosen for this set of experiments due to their low migratory capacity and complete lack of MMP-9 expression, thereby minimizing 
A
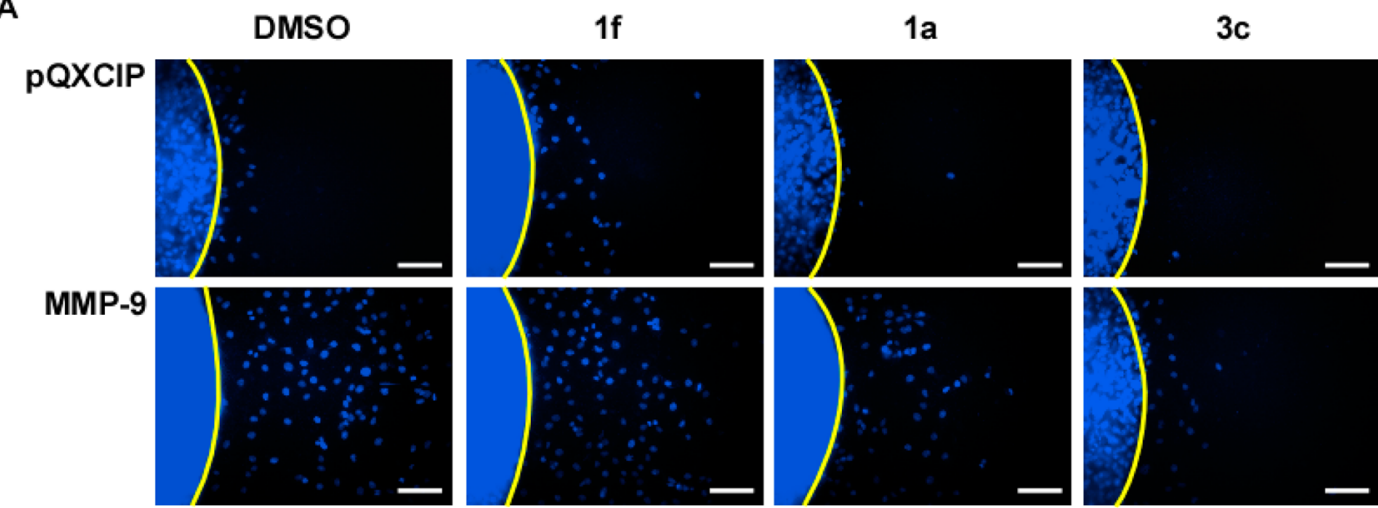

B
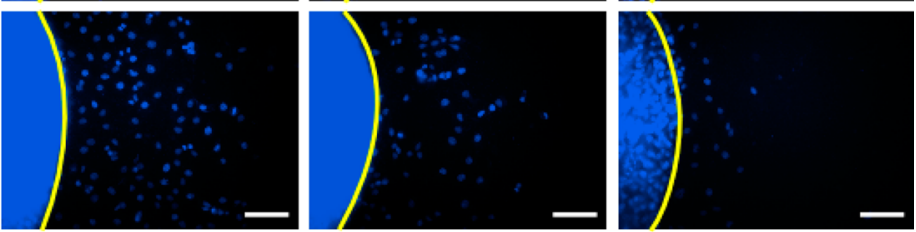

B
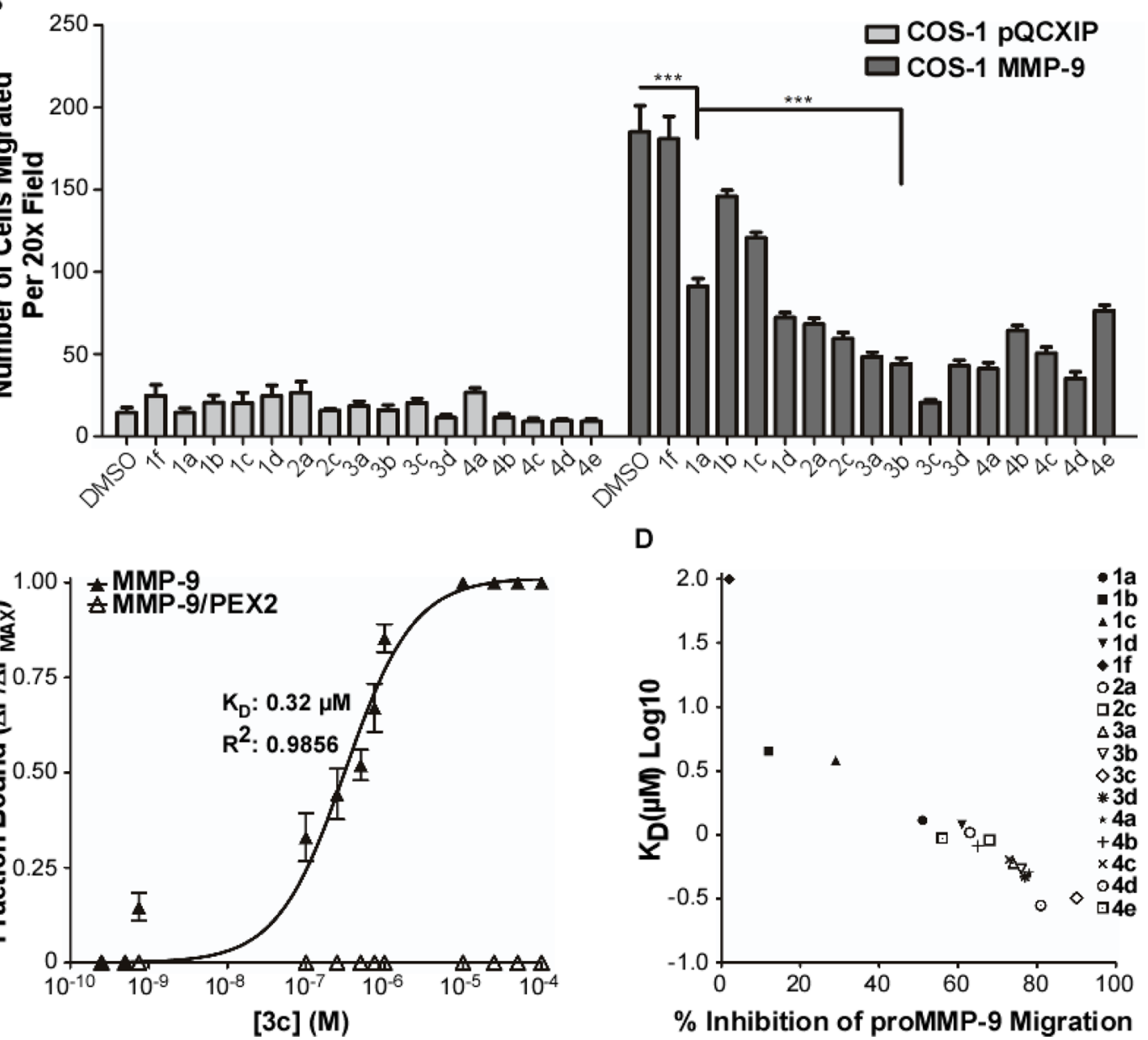

。

D

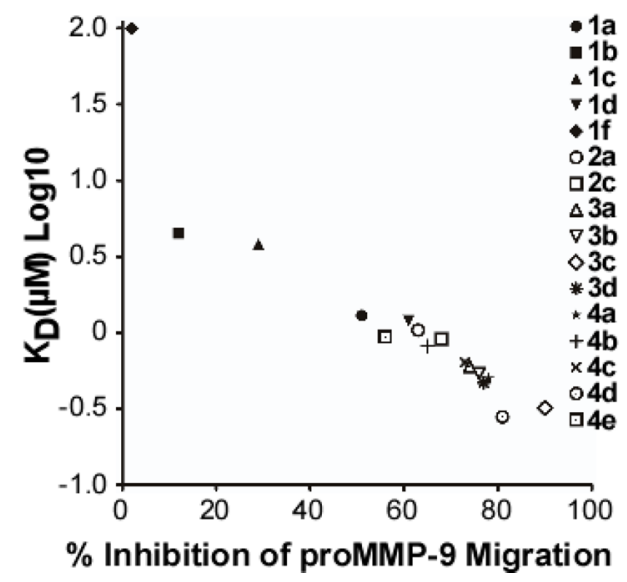

Figure 2. Structure-activity relationship analysis of all synthesized PEX-9 inhibitor derivatives. (A) Representative 20X magnification DAPI images of COS-1 cells engineered to stably express either vector control or proMMP-9 cDNA vectors in a two-dimensional migration assay after treatment with $50 \mu \mathrm{M}$ of 1f, 1a, or 3c. Scale bar $=250 \mu \mathrm{m}$. (B) Quantitative analysis of migrated COS-1 vector control and proMMP-9 expressing cells after treatment with $50 \mu \mathrm{M}$ of inhibitors. (C) Tryptophan fluorescence emission of proMMP-9 or proMMP-9/PEX2 (ex, $280 \mathrm{~nm}$; em, $330 \mathrm{~nm}$ ) was monitored and inhibitor $3 \mathrm{c}$ titrated into the protein solution. A maximal $\lambda_{\mathrm{Max}}$ shift of $9 \mathrm{~nm}$ was observed after treatment with $25 \mu \mathrm{M}$ inhibitor. A solid line is a curve fit for $K_{\mathrm{d}}$ for compound $3 \mathrm{c}$ that was determined. (D) $K_{\mathrm{d}}$ for each inhibitor was plotted against percent inhibition of proMMP9mediated cell migration for each inhibitor.

potential artifacts when interpreting the data. Overexpression of proMMP-9 results in enhanced cell migration in a twodimensional dot migration assay. ${ }^{27}$ This assay was initially used to test the efficacy of analogs at a single concentration, $50 \mu \mathrm{M}$. This concentration was used as a maximal cutoff because concentrations above $50 \mu \mathrm{M}$ compound 1a did not increase inhibitor effectiveness in COS-1 cells.
Cells were mixed with type I collagen solution with or without the compound, dotted onto a 96-well plate, and allowed to migrate for $18 \mathrm{~h}$. They were then fixed, stained, and scored for the extent of migration (Figure $2 \mathrm{~A}$ and B). 2-(4Oxo-6-propyl-1,4-dihydropyrimidin-2-ylthio)-N(methyl)-phenylacetamide (1f) was used as a negative control. ${ }^{27}$ Compound $3 c$ was the most effective and was selected for further study. The migration assay was repeated in HT1080 fibrosarcoma 
A

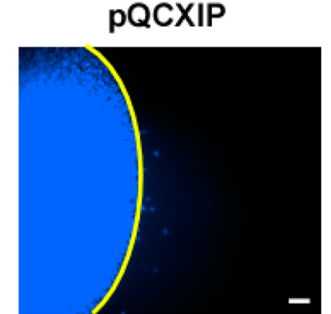

B

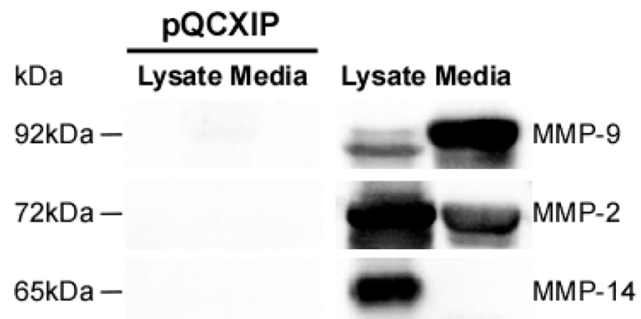

MMP-9

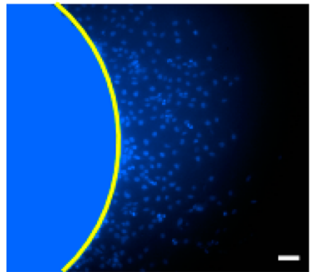

C
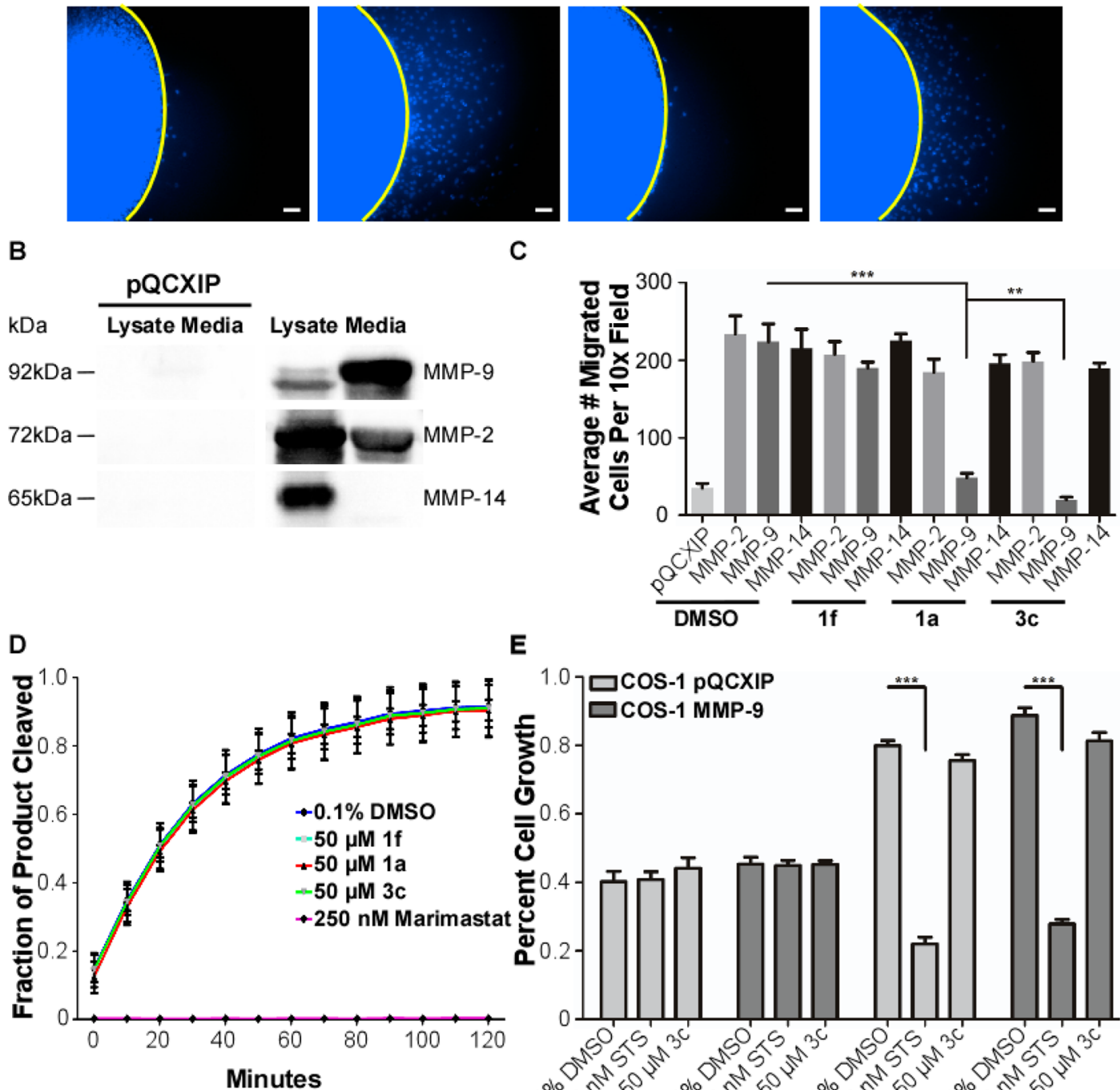

E

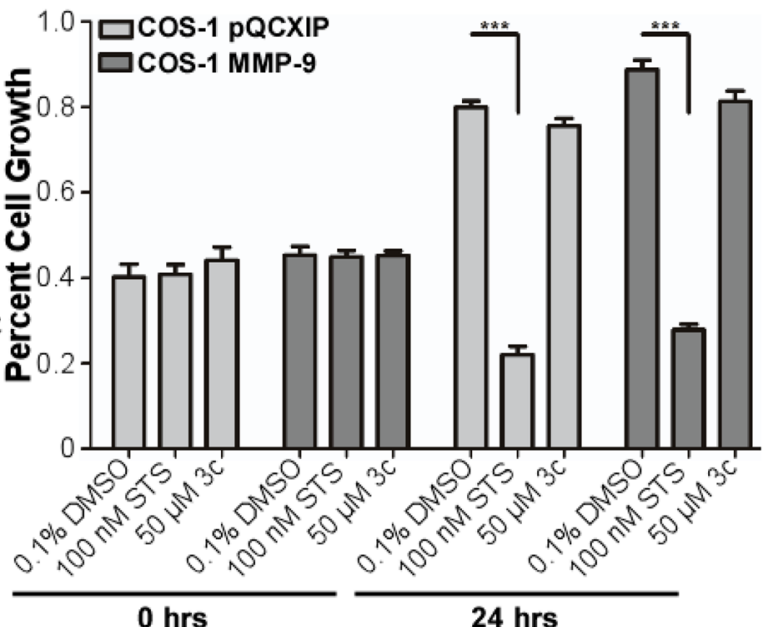

Figure 3. Determination of PEX-9 inhibitor specificity in the presence of homologous and nonhomologous MMPs. (A) COS-1 cells transiently transfected with either vector control, proMMP-2, proMMP-9, or MMP-14 cDNAs were treated with $50 \mu \mathrm{M}$ compound $3 \mathrm{c}$ and then used in a twodimensional dot migration assay. Representative 10× DAPI magnification images were taken and are shown. Scale bar $=250 \mu \mathrm{m}$. (B) MMP expression and proper localization was confirmed by immunoblot analysis of cell lysates and protein precipitated serum-free medium. pQCXIP is the vector only control. (C) Quantification of inhibition proMMP-9 mediated cell migration by compounds 1a and 3c. Compound 1f was used as a negative control. (D) Assay of MMP-9 catalytic activity using a fluorogenic peptide degradation assay and activated MMP-9. proMMP-9 protein was activated with $1 \mathrm{mM}$ APMA overnight. A total of $100 \mathrm{ng}$ of activated MMP-9 was incubated with $10 \mu \mathrm{M}$ fluorogenic peptide (excitation, $320 \mathrm{~nm}$; emission, $405 \mathrm{~nm}$ ) in the presence of buffer; $50 \mu \mathrm{M}$ compound 1a, 3c, or 1f; or $250 \mathrm{nM}$ broad-spectrum catalytic inhibitor Marimastat. Readings were performed every $10 \mathrm{~min}$ over the course of $2 \mathrm{~h}$. (E) Cell viability was assayed with MTT. COS-1 cells engineered to stably express either vector control or proMMP-9 cDNA were treated for $24 \mathrm{~h}$ with DMSO control, $50 \mu \mathrm{M}$ compound $3 \mathrm{c}$, or $100 \mathrm{nM}$ staurosporine (STS) as a positive control for acute cell toxicity.

cells, which endogenously express MMP-9, and the same inhibition potency was observed for both compound 1a and 3c relative to control groups (Supporting Information Figure $1 \mathrm{~A}$ and B).

Compound Affinity for PEX-9 Binding. A blue shift in proMMP-9 tryptophan fluorescence was monitored to determine the binding affinity of all derivative compounds as previously described. ${ }^{27}$ The $K_{\mathrm{d}}$ for compound $3 \mathrm{c}$ binding to proMMP-9 is $0.32 \mu \mathrm{M}$ (Figure $2 \mathrm{C}$ ), four times tighter than parent compound 1a. Moreover, a clear correlation between binding affinity and inhibition potency in the migration assay was observed (Figure 2D). Thus, the biophysical SAR is maintained in the cellular assay, and increased inhibition of cell migration is MMP9-dependent and due to optimization of the chemical structure for binding the PEX-9 domain.

PEX-9 Binding Specificity. A chimera of proMMP-9 and MMP-2 in which the MMP-9 PEX domain was replaced by that of MMP-2 (proMMP-9/MMP-2PEX) ${ }^{11}$ was tested for analog binding. The tryptophans in the MMP-9 PEX domain are conserved in the MMP-2 PEX domain. Upon titration of compound $3 \mathrm{c}$ with the chimera, no shift in fluorescence was 
A

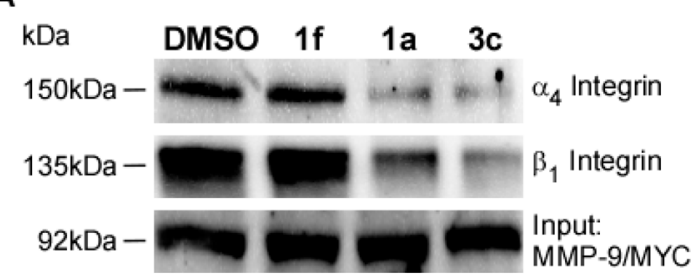

C

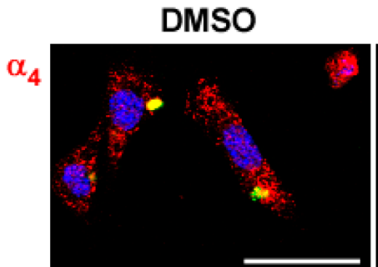

$\beta_{1}$
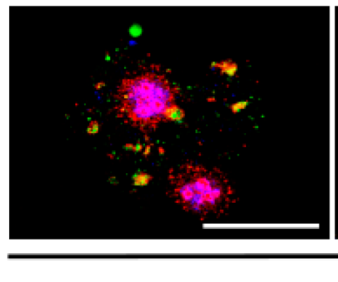

D

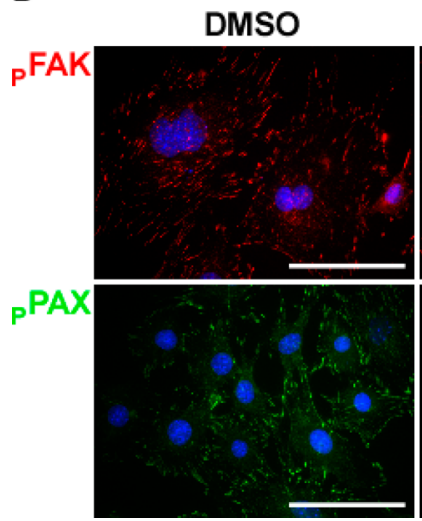

$1 f$
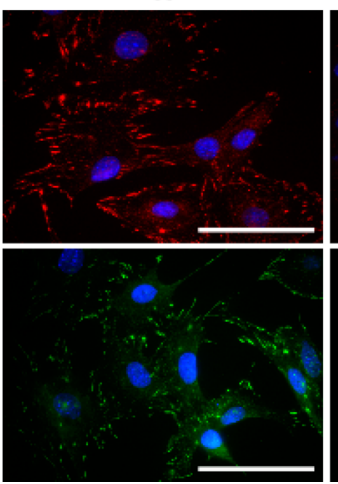

B

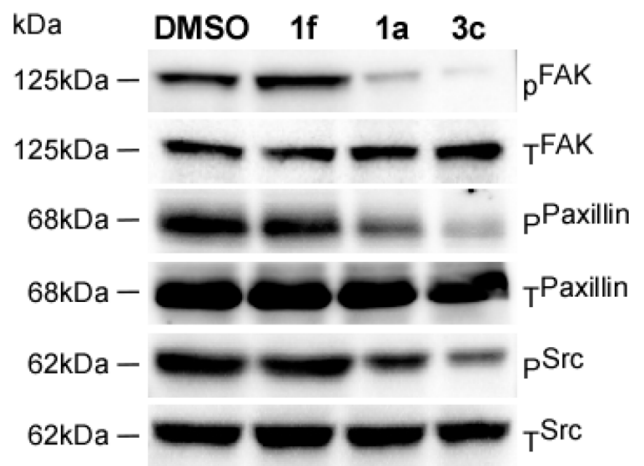

$1 a$

$3 c$
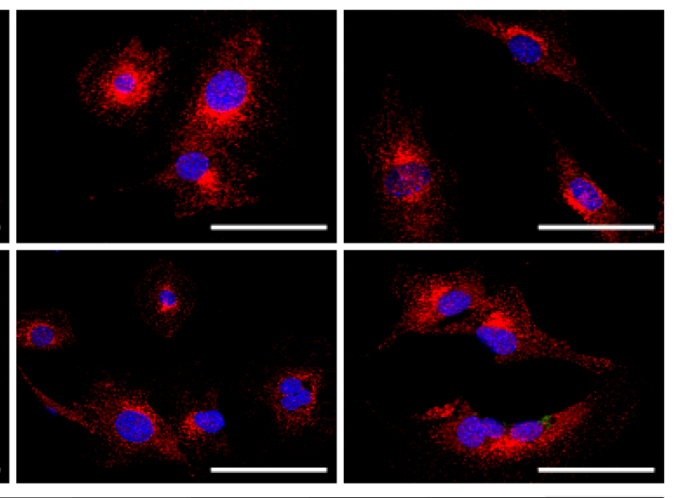

+ MMP-9

$1 a$

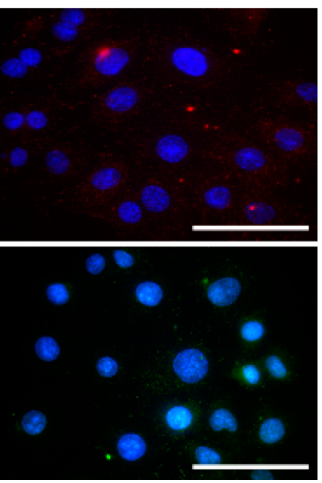

$3 c$

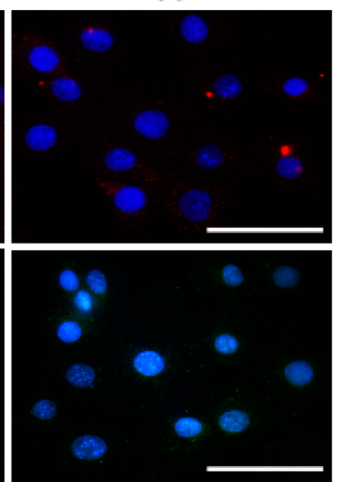

Figure 4. Treatment with PEX-9 inhibitor resulting in decreased interaction between MMP-9 and $\alpha 4 \beta 1$ integrin and attenuated downstream signaling. (A) Co-IP with HT1080 cells transiently overexpressing MMP-9/MYC cDNA was performed in the presence of $50 \mu \mathrm{M}$ compound 3c. MMP-9/MYC was immunoprecipitated using an anti-Myc antibody and served as an input control while $\alpha 4$ and $\beta 1$ integrin interactions were probed via immunoblot. A decrease in MMP-9 interacting with both integrin subunits was observed as well as a (B) decrease in Src ${ }^{\text {Tyr418 }}$ and downstream target proteins $\mathrm{FAK}^{\mathrm{Tyr}}$ 576/577 $/ \mathrm{PAX}^{\text {Tyr118 }}$ phosphorylation. (C) $60 \times$ confocal images were captured, and representative images of MMP-9 (green) and each integrin subunit (red) were taken after treatment of HT1080 cells with $50 \mu \mathrm{M}$ of either compound 1a, 3c, or 1f. Scale bar $=100$ $\mu \mathrm{m}$. (D) $60 \times$ confocal images were captured, and representative images of $\mathrm{p}^{-F_{1}} \mathrm{FKr}^{\mathrm{Ty}} 576 / 577$ (red) and p-PAX ${ }^{\mathrm{Tyr} 118}$ (green) were taken after treatment of HT1080 cells with $50 \mu \mathrm{M}$ of either compound 1a, 3c, or 1f. Scale bar $=100 \mu \mathrm{m}$.

observed suggesting that $3 \mathrm{c}$ does not bind to MMP2-PEX (Figure 2C).

As an additional test of binding selectivity, saturated transfer difference (STD) NMR was performed with purified recombinant proMMP-2 and proMMP-9 protein. ProMMP-2 and proMMP-9 are highly similar in structure and function, belonging to the same subfamily of MMPs known as the type IV collagenases and/or gelatinases. Thus, proMMP-2 constitutes the best control for testing the selectivity of the PEX-9 inhibitor. $^{28}$ Selective saturation of the $1.12 \mathrm{ppm}$ resonance (proMMP-2 and proMMP-9) was used for STD NMR spectra.
STD peaks were observed in the presence of proMMP-9, but not in the presence of proMMP-2, indicating that derivative compound $3 c$ is specific for the PEX-9 target (Supplemental Figure $2 \mathrm{~A}-\mathrm{F}$ ). Thus, binding specificity is maintained upon increasing binding affinity.

PEX-9 Inhibitor Target Specificity. To test whether compound $3 \mathrm{c}$ is specific for inhibiting only proMMP9mediated migration, a two-dimensional dot migration assay was performed using COS- 1 cells engineered to stably express vector control pQCXIP, proMMP-2, proMMP-9, or proMMP14 cDNA vectors (Figure $3 \mathrm{~A}$ ). An immunoblot was performed 
to confirm protein expression and proper localization of each MMP (MMP-2/-9 are secreted while MMP-14 is membrane bound; Figure 3B). As expected, expression of these three MMPs resulted in enhanced cellular migration in COS- 1 cells. ${ }^{11}$ Treatment with either compound $\mathbf{1 a}$ or $3 \mathbf{c}$ only inhibited proMMP9-mediated migration: compound $3 c$ was significantly more effective at inhibiting migration (Figure 3C).

Effect of PEX-9 Inhibitor on MMP-9 Catalytic Activity. Recombinant proMMP-9 protein was purified and incubated overnight in a $37^{\circ} \mathrm{C}$ water bath in TNC buffer $+1 \mathrm{mM}$ APMA to artificially activate the protein. ${ }^{29,30}$ The next day, the purified protein was incubated with $10 \mu \mathrm{M}$ fluorogenic peptide (McaPro-Leu-Gly-Leu-Dpa-Ala-Arg-NH2), and catalytic activity was monitored over $2 \mathrm{~h}$ in the presence of compounds $\mathbf{1 a}, 3 \mathbf{c}, \mathbf{1 f}$, and marimastat, a broad-spectrum MMP catalytic inhibitor. No inhibition of the catalytic activity was observed with 1a or $3 c$, corroborating that PEX-9 inhibitors do not modulate the catalytic activity of the protease. In the presence of marimastat $\left(K_{\mathrm{d}}=80 \mathrm{nM}\right)$, no substrate cleavage was observed (Figure 3D). Therefore, inhibition of proMMP9-mediated cell migration by compound 1a or $3 \mathrm{c}$ is not due to a loss of proteolytic activity.

Cell Viability Analysis. Compound 3c was evaluated for acute cytotoxicity. COS-1 cells stably expressing either vector control or proMMP-9 cDNA were treated with $50 \mu \mathrm{M} 3 \mathrm{c}$ for $24 \mathrm{~h}$. As negative and positive controls, cells were treated with DMSO alone or $100 \mathrm{nM}$ staurosporine (STS), an apoptosis inducer, respectively. ${ }^{31}$ Significant cell death was only observed after treatment with STS. A nonstatistically significant $8 \%$ decrease in cell growth occurred after treatment with $50 \mu \mathrm{M}$ of compound 3c (Figure 3E). These experiments were repeated in endogenous MMP-9 expressing HT1080 fibrosarcoma cells, which were analyzed for chronic toxicity (cells were retreated every 3 days for a total of 9 days). No cell death was observed at $100 \mu \mathrm{M} 3 \mathrm{c}$ (data not shown).

PEX-9 Inhibitors Decrease MMP-9 Dimer Formation and Association with EGFR. Human fibroscarcoma HT1080 cells were cotransfected with MMP-9 cDNAs tagged with either a Myc or HA tag as previously reported. ${ }^{12}$ The next day, cells were switched to serum free media and treated with $50 \mu \mathrm{M}$ of either compound 1a or 3c overnight. Using the Myc antibody for immunoprecipitation and HA antibody for immunoblotting, the formation of dimeric MMP-9 was monitored. Compound 3c significantly blocked MMP-9 dimer formation as compared to control compound 1f. In addition, inhibition of PEX-9 with 1a or $3 c$ reduced endogenous CD44 and EGFR coimmunoprecipitation (Supporting Information Figure 3A). Moreover, these PEX-9 inhibitors reduced phosphorylation of EGFR ${ }^{\text {Tyr1068 }}$ and its downstream targets $\mathrm{AKT}^{\mathrm{Ser} 473}$ and Erk1/2 $2^{\mathrm{Thr} 202 / \mathrm{Tyr}^{204}}$ (Supporting Information Figure 3B).

PEX-9 Inhibitors Disrupt MMP-9 Interaction with $\alpha 4 \beta 1$ Integrin. HT1080 cells transiently cotransfected with tagged MMP-9 cDNAs were prepared as described above. ${ }^{12}$ Inhibition of PEX-9 with $50 \mu \mathrm{M}$ of either compound 1a or $3 \mathrm{c}$ reduced endogenous $\alpha 4 \beta 1$ integrin coimmunoprecipitation (Figure 4A). Inhibition of PEX-9 with $50 \mu \mathrm{M}$ of either compound $1 \mathrm{a}$ or $3 \mathrm{c}$ reduced $\mathrm{Src}^{\mathrm{Ty} 418}$ phosphorylation in addition to phosphorylation of Src downstream targets FAK $^{\text {Tyr } 576 / 577}$ and PAX ${ }^{\text {Tyr118 }}$ (Figure 4B).

Evaluation of MMP-9 Cell Surface Localization upon Treatment with PEX-9 Inhibitors. HT1080 cells were fixed in $4 \%$ paraformaldehyde then subsequently incubated with antiMMP-9 in addition to anti- $\alpha 4$ and/or $\beta 1$ integrin antibodies to monitor relative levels of localization of these proteins at the cell surface. The cells were counterstained with DAPI nuclear dye. Treatment with either compound $\mathbf{1 a}$ or $3 \mathrm{c}$ resulted in a loss of MMP-9 from the cell surface (Figure 4C). However, treatment with either solvent control DMSO or negative control compound 1f did not disrupt the localization of MMP-9 on the cell surface.

Evaluation of Focal Adhesion Complexes in the Presence of PEX-9 Inhibitors. HT1080 cells were fixed after overnight treatment with $50 \mu \mathrm{M}$ PEX-9 inhibitors, probed for either $\mathrm{FAK}^{\mathrm{Tyr}} 576 / 577$ or $\mathrm{PAX}^{\mathrm{Tyr} 118}$ and counterstained with DAPI. A decrease in the formation of FAK and PAX adhesion junctions, normally depicted as "large punctae," was observed in cells after treatment with PEX-9 inhibitor compound 1a or 3c (Figure 4D).

Validation of MMP-9's Role in Signaling. MMP-9 expression was silenced using an shRNA approach as previously described. ${ }^{12}$ HT 1080 cell lysates were collected and analyzed by immunoblot. Attenuation of MMP-9 expression resulted in a decrease in the phosphorylation of EGFR ${ }^{\text {Tyr1068 }}$, FAK ${ }^{\text {Tyr }}$ 576/577, $\mathrm{PAX}^{\text {Tyr118 }}$, Src $^{\text {Tyr418 }}$, AKT ${ }^{\text {Ser473 }}$, and Erk1/2 ${ }^{\text {Thr202/Tyr204 }}$ (Supporting Information Figure 4A). These findings are corroborated by Kinexus antibody microarray screening of phosphorylationdependent signaling pathways in MMP-9-transfected COS-1 cells ${ }^{12}$ in which Src, FAK, and PAX phosphorylation increase in proMMP-9 overexpressing cells (Supporting Information Figure 4B).

Treatment with PEX-9 Inhibitor Prevents Association of EGFR with CD44 and $\beta 1$ Integrin. HT1080 cells were treated with $50 \mu \mathrm{M} 3 \mathrm{c}, \mathbf{1 a}, \mathbf{1 f}$, or DMSO alone. Cell lysates were collected and analyzed by a co-IP assay in which endogenous EGFR was captured with an anti-EGFR antibody and served as an input control. CD44 and $\beta 1$ integrin were individually probed on the immunoblot. Decreased interaction between EGFR-CD44 and EGFR- $\beta 1$ integrin was observed after treatment with $3 c$ (Supporting Information Figure 5A).

Src Activation is a PEX-9 Dependent Process. NonMMP-9 expressing MCF-7 breast cancer cells were transiently transfected with either vector control pcDNA3.1, proMMP-9, or chimeric proMMP-9/MMP-2PEX cDNA constructs. Phosphorylation of $\mathrm{Src}^{\text {Tyr418 }}$ was detected using an immunoblotting assay. Increased $\mathrm{Src}^{\text {Tyr418 }}$ phosphorylation was observed in proMMP-9 overexpressing cells. PEX domain swapping with MMP-2 has no effect on $\mathrm{Src}^{\mathrm{Tyr} 418}$ phosphorylation, similar to vector control pcDNA3.1 expressing cells (Supporting Information Figure 5B).

Effect of PEX-9 Inhibitors on Cell Adhesion. A 96-well plate was coated with a thin layer of either collagen or fibronectin $(5 \mu \mathrm{g} / \mathrm{mL}$ in PBS) substrate before use. HT1080 cells were then seeded onto wells and incubated at $37^{\circ} \mathrm{C}$ for 30 min in the presence of various inhibitors. Wells were washed and cells were fixed in $4 \%$ paraformaldehyde and stained with DAPI. Images of each 96-well plate were microscopically captured and counted for the number of cells still adherent to the coated surface using automated computer software. Compound 1a or 3c inhibited cellular adhesion, whereas treatment with Marimastat, a broad-spectrum MMP catalytic inhibitor, had no observable effect on cell attachment. Solvent DMSO and compound If also had no effect on cell adhesion (Supporting Information Figure 6A).

Effect of Broad-Spectrum MMP Catalytic Inhibitor Marimastat on Focal Adhesion Complexes. HT1080 cells treated with $80 \mathrm{nM}$ of broad-spectrum MMP inhibitor marimastat were analyzed by immunofluorescence microscopy 
A
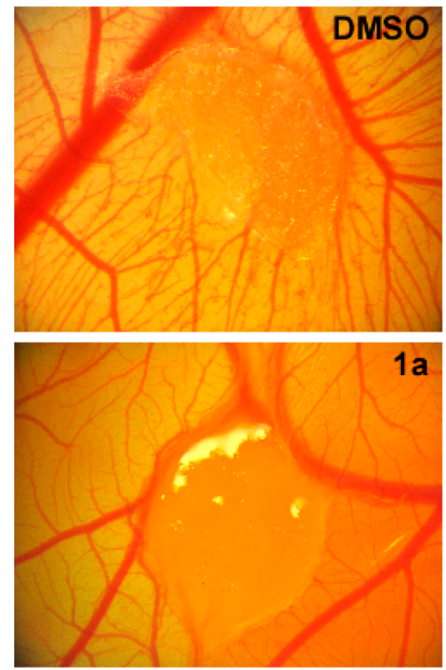

C
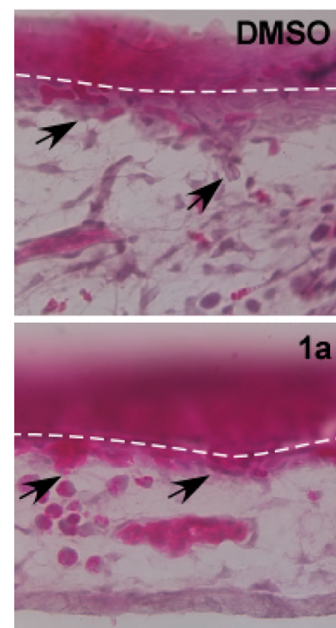
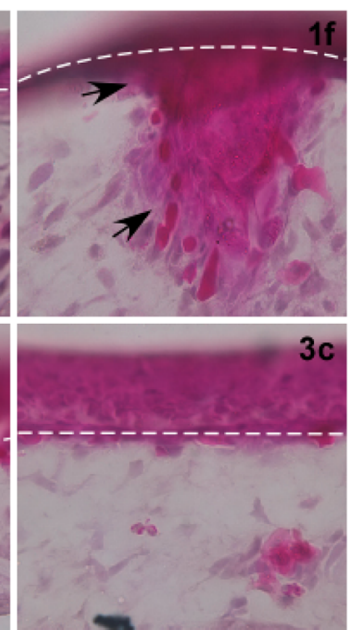
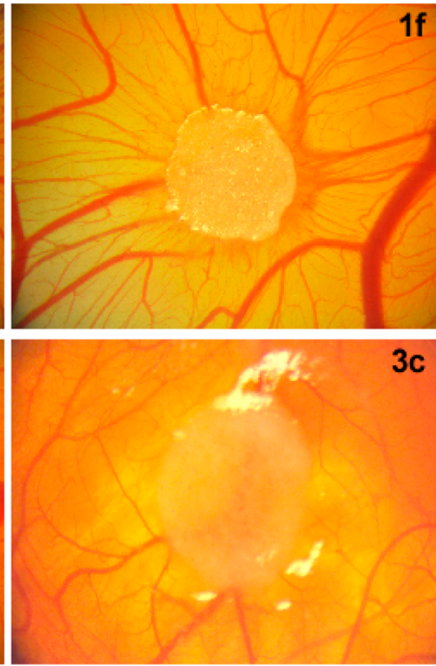

sc

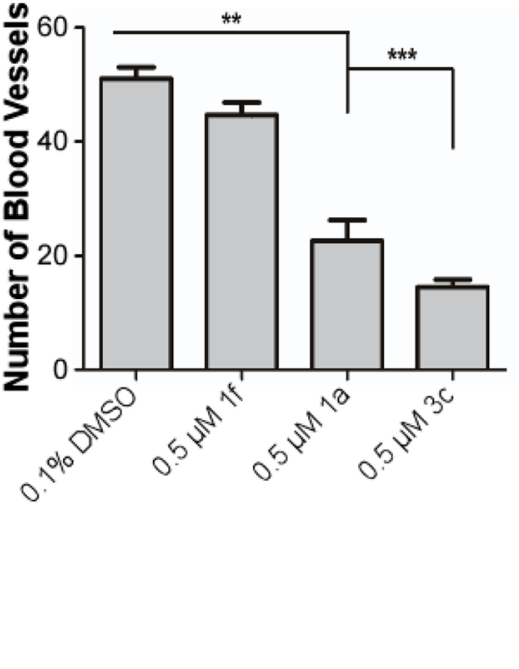

D
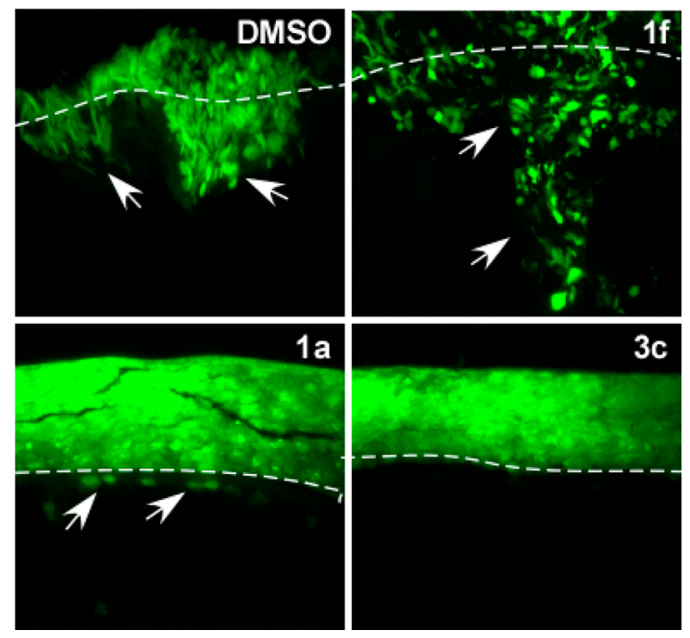

Figure 5. Compound 3c prevents angiogenesis and invasion through the basement membrane in a CAM assay. (A) HT1080 cells were adsorbed onto a gelatin sponge, implanted atop the CAM, and then subsequently treated with DMSO control or $0.5 \mu \mathrm{M}$ compound 1f, 1a, or $3 \mathrm{c}$. After 4 days of incubation at $37^{\circ} \mathrm{C}$, representative images of the angiogenic bed surrounding the gelatin sponge were taken. (B) Analysis and quantification of the number of blood vessels in the area surrounding the implanted sponge. (C, D) The CAM was inoculated with $\mathrm{HT}_{1080} \mathrm{GFP}^{+}$cells mixed with a type I collagen solution and treated with DMSO control and $0.5 \mu \mathrm{M}$ compound 1f, 1a, or $3 \mathrm{c}$. After 7 days of incubation at $37{ }^{\circ} \mathrm{C}$, CAM membranes were isolated, sectioned, H\&E stained, and imaged under $20 \times$ magnification.

for both $\mathrm{p}-\mathrm{FAK}^{\mathrm{Tyr}}$ 576/577 and p-PAX ${ }^{\mathrm{Ty} 118}$. Treatment with marimastat did not prevent the formation of focal adhesion contact sites in HT1080 cells (Supporting Information Figure 6B).

Treatment with PEX-9 Inhibitor Prevents Both Angiogenesis and Invasion in a Chorioallantoic Membrane (CAM) Assay. A CAM assay was carried out to evaluate angiogenic and invasive potential of HT1080 cells after treatment with 3c. HT1080 cells were adsorbed onto a gelatin sponge and implanted onto the surface of the chicken embryo CAM followed by treatment with a $100 \mu \mathrm{M}$ stock solution of compound 1f, 1a, or 3c (final drug concentration is estimated to be $0.5 \mu \mathrm{M}$ ). After a 4-day incubation, neovascularization was imaged and quantified. Treatment with either compound 1a or 3c significantly reduced the angiogenic potential of HT1080 cells as compared to solvent DMSO and negative compound if control treated cells (Figure 5A,B).

HT1080 cells stably expressing GFP were mixed with a type I collagen solution $\left(3 \mathrm{mg} \mathrm{mL}^{-1}\right)$ and seeded atop the CAM to ensure the cells localized to a specific area. Then, they were treated with a $100 \mu \mathrm{M}$ stock solution of compound 1f, $1 \mathrm{a}$, or $3 \mathrm{c}$ (final drug concentration is estimated to be $0.5 \mu \mathrm{M}$ ). The invasion of cancer cells through the epithelium and basement membrane of the upper CAM into connecting tissue was examined by hematoxylin and eosin staining (Figure 5C) in addition to fluorescence microscopy for $\mathrm{GFP}^{+}$cells (Figure 5D). Treatment of HT1080 cells with either compound 1a or $3 \mathrm{c}$ reduced invasion of CAM tissue compared to treatment with either DMSO or compound $\mathbf{1 f}$ control.

\section{DISCUSSION}

MMPs are crucial for the degradation of ECM and blood vessel linings. Degradation allows tumor cells to escape their primary location and enter the circulatory system where they can travel to seed secondary tumors elsewhere in the body. ${ }^{32,33}$ Therefore, targeting MMPs with inhibitors is of interest for cancer drug development. $^{34}$ Original inhibition attempts focused on 
A

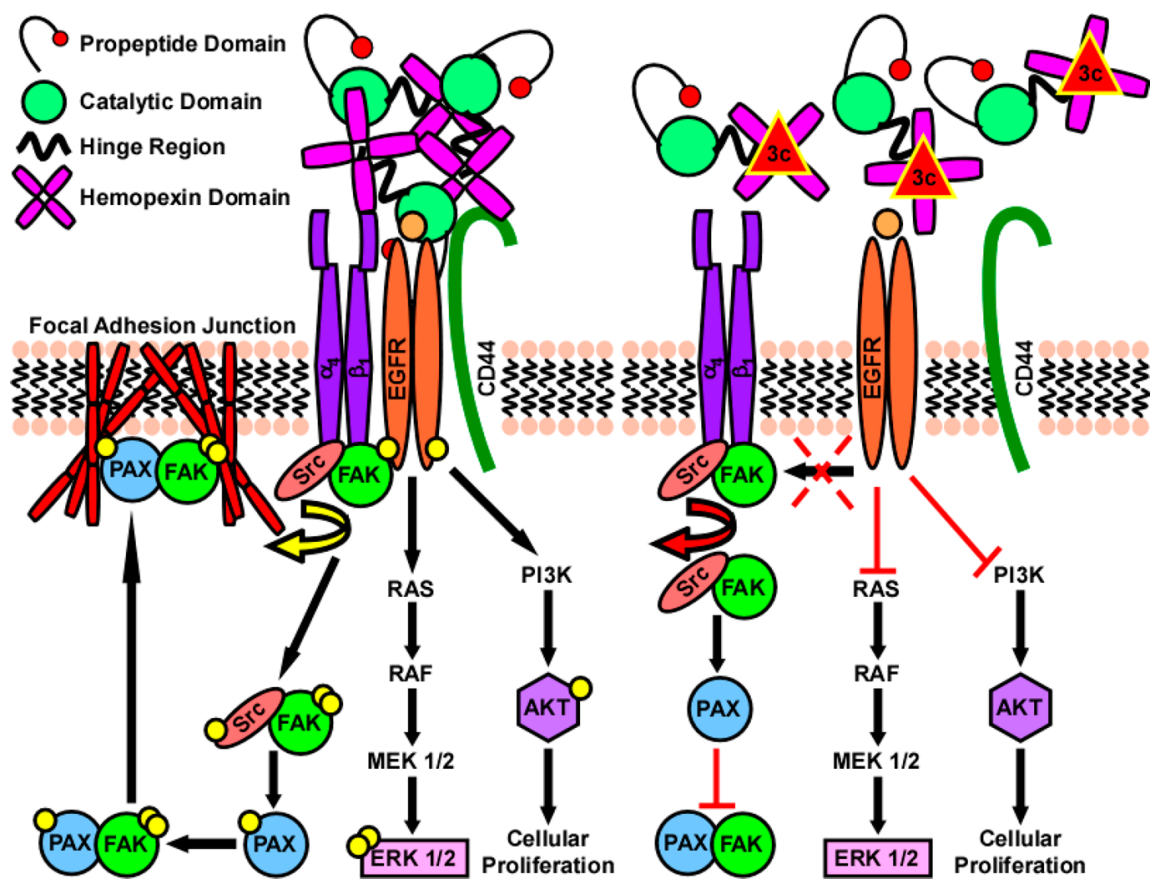

Figure 6. Overview of the mechanism by which MMP-9 regulates formation of focal adhesion junctions. (A) During exocytosis and upon being secreted into the extracellular space, proMMP-9 forms a large complex with itself that can then act as a scaffold for promoting outside-in signaling. In our model, PEX-9 scaffolding promotes the association of $\beta 1$ integrin-EGFR-CD44. Interaction with CD44 results in enhanced EGFR activation in addition to increased phosphorylation of its downstream targets AKT and Erk $1+2$ (through the MAPK/Erk pathway). While complexed to $\beta 1$ integrin, EGFR then goes on to transactivate Src kinase after it is recruited to the $\alpha 4$ integrin subunit during the generation of a new focal adhesion contact site. After activation, Src can then directly phosphorylate FAK currently associated with the $\beta 1$ integrin subunit resulting in its maximal catalytic activity. This active Src-FAK complex can then bind and activate PAX, resulting in a mature FAK-PAX complex necessary for the formation of focal adhesion junctions. Formation of a complex between FAK and PAX results in final translocation to ECM-integrin junctions at the cell surface where they regulate cytoskeletal interactions resulting in enhanced cellular adhesion, migration, and invasion of cancer cells. (B) Treatment with PEX-9 inhibitor (depicted as red triangle) prevents MMP-9 scaffolding, thereby preventing downstream signaling driven by EGFR activation.

synthetic collagen-mimicking hydroxamate inhibitors that chelate the zinc ion in the active site upon binding. ${ }^{35}$ These drugs largely failed in clinical trials due to lack of selectivity for individual MMPs. Due to the specificity issues inherent in generating inhibitors of MMP proteolytic activity, we developed inhibitors which target MMP-9's hemopexin domain. MMP hemopexin domains share a common tertiary structure, yet the surface residues of MMP hemopexin domains are distinct, and one hemopexin domain cannot functionally substitute for another.

Identification of a More Potent PEX-9 Inhibitor. To identify compounds that bind more tightly to the hemopexin domain of MMP-9 than our original hit, ${ }^{27}$ structural diversity was introduced at three positions and computational DOCKing utilized to prioritize synthesis and testing of a small subset. The similarities between their predicted and measured binding affinities indicate that the DOCKed structures may be used to infer important binding modalities. Compounds that displayed the greatest inhibition of proMMP-9 mediated migration had longer linkers with three methylenes between the amide and the sulfide moieties and at least one fluorine in the $\mathrm{R}^{1}$ group. A cluster of derivative compounds (2c, 3a-3c, 4a, 4d) shared a similar binding geometry within the hemopexin domain of MMP-9 (Figure 1C). In all the tightest binding PEX-9 inhibitor derivatives, the aryl fluorine atoms were found deep within the binding pocket in contrast to the original hit 1a, in which the difluoromethoxyphenol moiety remained solvent exposed. The STD-NMR data support the binding pose in which the aniline is deeply buried in the pocket (Supporting Information Figure $2 \mathrm{~A}-\mathrm{F}$ ). In addition, fusion of a second ring to the pyrimidone moiety to form a quinazolinone significantly improved inhibitor efficiency and affinity. The length of the aliphatic chain between the two ring moieties is key for optimizing binding interactions. Comparison of DOCKed compounds $\mathbf{1 a}$ and $3 \mathrm{c}$ highlights differences in binding orientation that may contribute to the higher affinity of 3c (Figure 1D).

Binding affinity for PEX-9 correlates with inhibition of proMMP9-mediated migration (Figure 2D) across our 16compound series that spans 1.5 logs of binding affinity. These structure-activity results support the mechanism of inhibition of proMMP9-dependent cell migration being through targeting PEX-9 on the cell surface.

proMMP-9 homodimerization is a critical step for interaction with CD44 at the cell surface, which results in decreased phosphorylation of $\mathrm{EGFR}^{\mathrm{Tyr} 1068}$ and its downstream targets $\mathrm{AKT}^{\text {Ser473 }}$ and Erk $1 / 2^{\text {Thr202/Tyr204 }}$ phosphorylation. ${ }^{12}$ Compound $3 \mathrm{c}$ demonstrated enhanced efficacy of blocking proMMP-9 homodimerization and activation of downstream protein targets (Figure 4, Supporting Information Figure 3). Moreover, our most potent compound, $3 \mathbf{c}$, retained specificity for a single MMP as demonstrated by the lack of inhibition in proMMP-2 or proMMP-14 mediated cell migration (Figure $3 \mathrm{C}$ ). Our structure-activity correlation (Figure 2D) and the specificity of inhibition for proMMP-9 mediated cell migration corroborate that compound $3 \mathrm{c}$ targets PEX-9 in vitro and in vivo 
and not a downstream signaling target common to other mediators of cell migration.

Recently, Garcia-Pardo and co-workers reported that the central cavity of PEX-9 interacts with $\alpha 4 \beta 1$ integrin as a mechanism for cross-talk between MMPs and integrin focal adhesion formation. ${ }^{17,18,21}$ In turn, Src kinase interacts with the cytoplasmic tail of $\alpha 4 \beta 1$ integrin subunits, which is critical for integrin function to promote and regulate focal adhesion turnover. $^{36-42}$ Interestingly, PEX9- $\alpha 4 \beta 1$ integrin downstream signaling increases activation of Fyn, a Src family kinase, and drives chronic lymphocytic leukemia B cell survival. ${ }^{17}$ Therefore, we examined the consequences of binding $3 c$ to PEX-9 on $\alpha 4 \beta 1$ integrin-mediated Src signaling.

Using a coimmunoprecipitation approach, we found that PEX-9 inhibitors interfere with binding between proMMP-9 and $\alpha 4 \beta 1$ integrin and can block cross-talk signaling. This disruption is accompanied by decreases in phosphorylation levels of $\mathrm{Src}^{\text {Tyr418 }}$ and its downstream substrates FAK $^{\mathrm{Tyr}}$ 576/577 and $\mathrm{PAX}^{\mathrm{T} y r 118}$ (Figure 4B). Immunofluorescence imaging in HT1080 cells further supported the idea that focal adhesion junctions ("large punctae") were lost upon treatment with the PEX-9 inhibitor (Figure 4C,D). We also demonstrated that overexpression of proMMP-9 in MCF-7 breast cancer cells enhanced Src activation. Overexpression of proMMP-9/ MMP2-PEX in MCF-7 breast cancer cells or silencing of endogenous MMP-9 expression in HT1080 attenuated Src activation. Taken together, the data suggest that the proMMP-9 hemopexin domain is required for enhanced cellular adhesion and migration.

Potential Mechanism by Which Src Is Activated. Our data are in agreement with the literature showing that $\alpha 4 \beta 1$ integrin clustering is sufficient for activation of Src kinase. ${ }^{37,43}$ However, in addition to integrin clustering, EGFR can directly activate Src kinase, and EGFR interacts with $\beta 1$ integrin. ${ }^{44-46}$

It is proposed that proMMP-9 forms a large charged surface for complex interactions with multiple surface proteins involved in outside-in signaling. ${ }^{47}$ The hemopexin domain of proMMP-9 may act as a scaffold to enhance clustering of $\alpha 4 \beta 1$ integrinEGFR-CD44 at the cell surface and result in aberrant Src activation. ${ }^{48}$ Garcia-Pardo and co-workers demonstrated that a peptide mimicking blade 1 of PEX-9 inhibits interaction with integrin and that a second peptide mimicking blade 4 of PEX-9 inhibits interaction with CD $44 .^{21,22}$ We reasoned that our inhibitor, which binds directly to PEX-9, could simultaneously disrupt both interactions. Indeed, our coimmunoprecipitation experiments demonstrate that the addition of $3 \mathrm{c}$ selectively disrupts proMMP-9 interaction with both $\alpha 4 \beta 1$ integrin (Figure 4) and CD44 (Supporting Information Figure S3).

Importantly, our inhibitor is specific for MMP-9. Targeting the hemopexin domain to investigate the role of MMP-9 in promoting cellular adhesion has identified a connection to integrin and Src in a complex adhesion network as depicted in Figure 6 . There are currently no effective cancer therapeutics designed to target adhesion receptors because cancer cells can change the mechanism by which they migrate depending upon their environmental constraints. ${ }^{49}$ Our in vivo CAM experiments demonstrate that we can inhibit two key determinants of tumor cell metastatic potential, angiogenesis and invasion (Figure 5), through PEX domain targeting. Our small molecule inhibitor paves the way for designing new therapeutic strategies for the treatment of metastatic disease and opens the door for the future development of new technologies and tools for understanding the role of individual MMPs in cancer progression. Development of PEX inhibitors for other MMPs will provide understanding of their noncatalytic functions and a strategy for reducing undesirable off-target effects previously observed in broad-spectrum MMP catalytic inhibitor clinical trials.

\section{EXPERIMENTAL METHODS}

Materials. Collagen type I (acetic-acid-extracted native type I collagen from rat tail tendon) was obtained from BD Bioscience Discovery Labware (Franklin Lakes, NJ). Fibronectin solution was purchased from Sigma-Aldrich (St. Louis, MO). Hoechst nuclear stain was obtained from Invitrogen (Grand Island, NY). Rabbit anti-p-

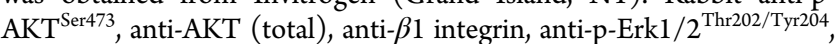
anti-p-FAK ${ }^{\text {Tyr } 576 / 577,}$ anti-FAK (total), anti-p-PAX ${ }^{\text {Tyr1 } 18}$, anti-PAX (total), and anti-EGFR (total) antibodies were all purchased from Cell Signaling Technology (Danvers, MA). Mouse anti-Erk1/2 (total), anti- $\beta$-actin, and anti- $\alpha / \beta$-tubulin antibodies were also purchased from Cell Signaling Technology (Danvers, MA). Rabbit anti-p-Src ${ }^{\text {Tyr418 }}$ and anti-Src (total) in addition to mouse anti- $\beta 1$ integrin were obtained from Abcam (Cambridge, MA). Mouse anti- $\alpha 4$ integrin and antiCD44 in addition to rabbit anti- $\alpha 4$ integrin were purchased from Santa Cruz Biotechnology (Santa Cruz, CA). Rabbit anti-MMP-9 was purchased from Millipore (Darmstadt, Germany). Rabbit pEGFR $^{\text {Tyr1068 }}$ was obtained from Enzo Life Sciences (Ann Arbor, MI). Rat anti-CD44 was obtained through BD Pharmingen (San Diego, CA). Mouse anti-HA was purchased from InvitrogenThermoFisher Scientific (Waltham, MA). Rabbit anti-MYC and antiHA in addition to horseradish peroxidase conjugated antirabbit, antimouse, and antirat antibodies were obtained from Rockland Immunochemicals (Gilbertsville, PA). Mouse anti-MYC was purchased from Roche Life Sciences (Branford, CT). Alexa Fluor 488 and 568 antirabbit/-mouse antibodies were purchased from Molecular Probes, Life Technologies (Grand Island, NY). proMMP-9 used in kinetic experiments was purchased from Biolegends (San Diego, CA). Mca-PLGL-Dpa-AR-NH $\mathrm{N}_{2}$ Fluorogenic MMP Peptide Substrate was purchased from R\&D Systems (Minneapolis, MN). Chemicals were purchased from Sigma-Aldrich, Fisher Scientific, and VWR International and used as received or purified before use by standard methods. Tetrahydrofuran was freshly distilled from sodium and benzophenone. Dichloromethane was also distilled immediately prior to use under nitrogen from calcium hydride. 2-(4-Oxo-6-propyl-1,4-dihydropyrimidin-2-ylthio)-N(methyl)-phenylacetamide (1f) was purchased from ChemBridge Corp. (San Diego, CA).

General Methods. ${ }^{1} \mathrm{H}$ and ${ }^{13} \mathrm{C}$ NMR spectra were measured on a Bruker 300, 400, 500, or $700 \mathrm{MHz}$ spectrometer. Melting points were measured on a Thomas-Hoover capillary melting point apparatus and are uncorrected. TLC was performed on Sorbent Technologies aluminum-backed Silica G TLC plates (Sorbent Technologies, 200 $\mu \mathrm{m}, 20 \mathrm{~cm} \times 20 \mathrm{~cm}$ ), and column chromatography was carried out on silica gel 60 (Merck, 230-400 mesh ASTM). High-resolution mass spectrometry analysis was carried out on an Agilent LC-UV-TOF mass spectrometer at the Mass Spectrometry facility of the Institute of Chemical Biology and Drug Discovery, Stony Brook University.

Chemical Synthesis of PEX-9 Inhibitor Compounds and Characterization Data. N-(4-Difluoromethoxyphenyl)-2-(4-oxo-6propyl-1,4-dihydropyrimidin-2-ylthio)acetamide (1a). To a solution of bromoacetic acid (170 mg, $1.25 \mathrm{mmol})$ and EDC. $\mathrm{HCl}(239 \mathrm{mg}$, $1.25 \mathrm{mmol})$ in dichloromethane $(6 \mathrm{~mL})$ was added aniline $(5 \mathrm{a}, 200$ $\mathrm{mg}, 1.25 \mathrm{mmol}$ ) and was stirred at RT overnight. After the completion of the reaction, the reaction mixture was diluted with dichloromethane and washed twice with $1 \mathrm{~N}$ hydrochloric acid, twice with a saturated solution of sodium bicarbonate and twice with brine. The organic layers were collected, dried over magnesium sulfate, filtered, and concentrated to afford an off-white crude product. The crude product was recrystallized from hexanes/dichloromethane to give bromoacetanilide $6 \mathrm{a}$ as a white solid $(227 \mathrm{mg}, 65 \%$ yield $) .{ }^{1} \mathrm{H}$ NMR $(300 \mathrm{MHz}$, CDCl3): $\delta 4.27(\mathrm{~s}, 2 \mathrm{H}), 6.30-6.79(\mathrm{~s}, 1 \mathrm{H}), 7.21(\mathrm{~d}, 2 \mathrm{H}, J=9 \mathrm{~Hz})$, $7.63(\mathrm{~d}, 2 \mathrm{H}, J=9 \mathrm{~Hz})$. 
To a solution of sodium hydroxide $(7.2 \mathrm{mg}, 0.18 \mathrm{mmol})$ in water $(2$ $\mathrm{mL}$ ) was added 2-hydrosulfanyl-4-oxo-6-propyl-1,4-dihydropyrimidine (7; $30 \mathrm{mg}, 0.18 \mathrm{mmol}$ ), and the mixture was stirred until all of 1 was dissolved. To the mixture was added a solution of $6 \mathrm{a}(50 \mathrm{mg}, 0.18$ mmol) in tetrahydrofuran $(2 \mathrm{~mL})$ and heated at $60{ }^{\circ} \mathrm{C}$ for $2 \mathrm{~h}$ and then at $70{ }^{\circ} \mathrm{C}$ overnight. After the completion of the reaction, a white precipitate was observed, which was collected on a filter and recrystallized from ethanol to afford $1 \mathrm{a}$ as white solid $(42 \mathrm{mg}, 63 \%$ yield). Mp: $180{ }^{\circ} \mathrm{C}$ (decomp.). ${ }^{1} \mathrm{H}$ NMR (700 MHz, DMSO-d 6 ): $\delta$ $0.73(\mathrm{t}, J=7.0 \mathrm{~Hz}, 3 \mathrm{H}), 1.51(\mathrm{~m}, 2 \mathrm{H}), 2.32(\mathrm{t}, J=7.0 \mathrm{~Hz}, 2 \mathrm{H}), 4.05$ $(\mathrm{s}, 2 \mathrm{H}), 5.97(\mathrm{~s}, 1 \mathrm{H}), 6.97-7.29(\mathrm{~m}, 3 \mathrm{H}), 7.62(\mathrm{~d}, J=8.4 \mathrm{~Hz}, 2 \mathrm{H})$, $10.44(\mathrm{~s}, 1 \mathrm{H}) .{ }^{13} \mathrm{C}$ NMR $\left(175 \mathrm{MHz}, \mathrm{DMSO}-d_{6}\right): \delta 13.4,20.6,35.1$, $38.2,116.5 .0(\mathrm{t}, J=256.0 \mathrm{~Hz}), 119.5,120.4,136.4,146.3,165.9 .{ }^{19} \mathrm{~F}$ NMR (376 MHz, DMSO- $d_{6}$ ): $\delta-81.6$. HRMS (ESI+) calcd for $\mathrm{C}_{16} \mathrm{H}_{18} \mathrm{~F}_{2} \mathrm{~N}_{3} \mathrm{O}_{3} \mathrm{~S}[\mathrm{M}+\mathrm{H}]^{+}:$370.1031. Found: $370.1039(\Delta=-2.02$ ppm).

In the same manner, $\mathbf{1 b}$ and $\mathbf{1 c}$ were synthesized.

2-(4-Oxo-6-propyl-1,4-dihydropyrimidin-2-ylthio)-N-phenylacetamide (1b). White solid, $35 \%$ yield. Mp: $170{ }^{\circ} \mathrm{C}$ (decomposed). ${ }^{1} \mathrm{H}$ NMR $\left(700 \mathrm{MHz}\right.$, DMSO- $\left.d_{6}\right): \delta 0.83(\mathrm{t}, J=7.0 \mathrm{~Hz}, 3 \mathrm{H}), 1.46-1.56$ $(\mathrm{m}, 2 \mathrm{H}), 2.31(\mathrm{t}, J=7.0 \mathrm{~Hz}, 2 \mathrm{H}), 4.04(\mathrm{~s}, 2 \mathrm{H}), 5.90(\mathrm{~s}, 1 \mathrm{H}), 7.04(\mathrm{t}, J$ $=7.7 \mathrm{~Hz}, 1 \mathrm{H}), 7.30(\mathrm{t}, J=7.7 \mathrm{~Hz}, 2 \mathrm{H}), 7.56(\mathrm{t}, J=7.7 \mathrm{~Hz}, 2 \mathrm{H}), 10.33$ $(\mathrm{s}, 1 \mathrm{H}), 12.67(\mathrm{~s}, 1 \mathrm{H}) .{ }^{13} \mathrm{C}$ NMR $\left(175 \mathrm{MHz}\right.$, DMSO- $\left.d_{6}\right): \delta 13.4,20.5$, 35.1, 38.5, 119.0, 123.3, 128.7, 139.0, 165.9. HRMS (ESI+) calcd for $\mathrm{C}_{15} \mathrm{H}_{18} \mathrm{~N}_{3} \mathrm{O}_{2} \mathrm{~S}[\mathrm{M}+\mathrm{H}]^{+}:$304.1114. Found: $304.1113(\Delta=0.29 \mathrm{ppm})$.

$\mathrm{N}$-(4-Fluorophenyl)-2-(4-oxo-6-propyl-1,4-dihydropyrimidin-2ylthio)acetamide (1c). White solid, $69 \%$ yield. Mp: $191-194{ }^{\circ} \mathrm{C} .{ }^{1} \mathrm{H}$ NMR (500 MHz, DMSO- $\left.d_{6}\right): \delta 0.73(\mathrm{t}, J=7.0 \mathrm{~Hz}, 3 \mathrm{H}), 1.45-1.56$ $(\mathrm{m}, 2 \mathrm{H}), 2.31(\mathrm{t}, J=7.0 \mathrm{~Hz}, 2 \mathrm{H}), 4.02(\mathrm{~s}, 2 \mathrm{H}), 6.94(\mathrm{~s}, 1 \mathrm{H}), 7.10-$ $7.19(\mathrm{~m}, 2 \mathrm{H}), 7.55-7.62(\mathrm{~m}, 2 \mathrm{H}), 10.30(\mathrm{~s}, 1 \mathrm{H}), 12.54(\mathrm{~s}, 1 \mathrm{H}) .{ }^{13} \mathrm{C}$ NMR (500 MHz, DMSO- $d_{6}$ ): $\delta$ 13.4, 20.5, 35.0, 38.5, 115.3 (d, $J=$ $22.1 \mathrm{~Hz}), 120.7(\mathrm{~d}, J=7.7 \mathrm{~Hz}), 135.5(\mathrm{~d}, J=2.5 \mathrm{~Hz}), 158.0(\mathrm{~d}, J=$ $238.4 \mathrm{~Hz}), 165.8 .{ }^{19} \mathrm{~F}$ NMR $\left(376 \mathrm{MHz}, \mathrm{DMSO}-d_{6}\right): \delta-119.3$. HRMS (ESI+) calcd for $\mathrm{C}_{15} \mathrm{H}_{17} \mathrm{FN}_{3} \mathrm{O}_{2} \mathrm{~S}[\mathrm{M}+\mathrm{H}]^{+}:$322.1020. Found: $322.1020(\Delta=-0.03 \mathrm{ppm})$.

$\mathrm{N}$-(1H-benzo[d] imidazol-2-yl)-2-(4-oxo-6-propyl-1,4-dihydropyrimidin-2-ylthio)acetamide (1d). To a solution of thiouracil 7 (1.70 g, $10.0 \mathrm{mmol})$ and potassium carbonate $(2.07 \mathrm{~g}, 15.0 \mathrm{mmol})$ in $\mathrm{MeOH}$ $(10 \mathrm{~mL})$ and water $(20 \mathrm{~mL})$ was added ethyl 2-bromoacetate $(1.42 \mathrm{~g}$, $8.5 \mathrm{mmol}$ ). The mixture was stirred at RT for $15 \mathrm{~min}$ and $50 \mathrm{~mL}$ water was added. Then, the reaction mixture was extracted with ethyl acetate $(5 \times 80 \mathrm{~mL})$. The organic layers were combined and washed with water $(100 \mathrm{~mL})$ and brine $(100 \mathrm{~mL})$ and dried over $\mathrm{MgSO}_{4}$, and the solvent was removed by rotary evaporator. The crude product was purified by flash column chromatography on silica gel using $\mathrm{MeOH} /$ DCM as an eluent to give ethyl 2-(4-oxo-6-propyl-1,4-dihydropyrimidin-2-ylthio)acetate as a white solid (1.7 g, 67\% yield). Mp: 117$118{ }^{\circ} \mathrm{C} .{ }^{1} \mathrm{H}$ NMR $\left(300 \mathrm{MHz}, \mathrm{CDCl}_{3}\right): \delta 0.93(\mathrm{t}, J=7.2 \mathrm{~Hz}, 3 \mathrm{H}), 1.27$ $(\mathrm{t}, J=7.2 \mathrm{~Hz}, 3 \mathrm{H}), 1.59-1.65(\mathrm{~m}, 2 \mathrm{H}), 2.43(\mathrm{t}, J=7.2 \mathrm{~Hz}, 2 \mathrm{H}), 3.93$ $(\mathrm{s}, 2 \mathrm{H}), 4.20(\mathrm{q}, J=7.2 \mathrm{~Hz}, 2 \mathrm{H}), 6.05(\mathrm{~s}, 1 \mathrm{H}), 13.17(\mathrm{~s}, 1 \mathrm{H}) .{ }^{13} \mathrm{C}$ NMR $\left(175 \mathrm{MHz}, \mathrm{CDCl}_{3}\right): \delta 13.6,14.1,20.8,32.8,39.5,61.9,108.2$, 158.9, 165.5, 168.2, 169.2. HRMS (ESI+) calcd for $\mathrm{C}_{11} \mathrm{H}_{17} \mathrm{~N}_{2} \mathrm{O}_{3} \mathrm{~S}[\mathrm{M}$ $+\mathrm{H}]^{+}$: 257.0954. Found: $257.0953(\Delta=0.48 \mathrm{ppm})$.

To a solution of ethyl 2-((4-oxo-6-propyl-1,4-dihydropyrimidin-2yl)thio)acetate $(1.20 \mathrm{~g}, 4.68 \mathrm{mmol})$ in $\mathrm{MeOH}$ and water was added lithium hydroxide $(0.2 \mathrm{~g}, 9.36 \mathrm{mmol})$. The mixture was stirred at RT for 2 days. The reaction mixture was adjusted to $\mathrm{pH} 1$ by $1 \mathrm{~N}$ hydrochloric acid and extracted with ethyl acetate $(5 \times 80 \mathrm{~mL})$. The organic layers were combined and dried over $\mathrm{MgSO}_{4}$, and the solvent was removed by rotary evaporator to afford thioacetic acid $8(0.30 \mathrm{~g}$, $28 \%)$ as a white solid. Mp: $154-155^{\circ} \mathrm{C} .{ }^{1} \mathrm{H}$ NMR $(700 \mathrm{MHz}$, DMSO$\left.d_{6}\right): \delta 0.86(\mathrm{t}, J=7.0 \mathrm{~Hz}, 3 \mathrm{H}), 1.56(\mathrm{~m}, 2 \mathrm{H}), 2.30(\mathrm{t}, J=7.0 \mathrm{~Hz}, 2 \mathrm{H})$, $3.47(\mathrm{~s}, 2 \mathrm{H}), 5.79(\mathrm{~s}, 1 \mathrm{H}) .{ }^{13} \mathrm{C}$ NMR $\left(175 \mathrm{MHz}, \mathrm{DMSO}-d_{6}\right): \delta 13.6$, 20.7, 36.1, 38.2, 107.4, 163.7, 164.3, 166.3, 171.2. HRMS (ESI+) calcd for $\mathrm{C}_{9} \mathrm{H}_{13} \mathrm{~N}_{2} \mathrm{O}_{3} \mathrm{~S}[\mathrm{M}+\mathrm{H}]^{+}$: 229.0641. Found: $229.0644(\Delta=-1.11$ ppm).

To a mixture of 2-(6-oxo-4-propyl-1,6-dihydropyrimidin-2-ylthio)acetic acid $(8 ; 228 \mathrm{mg}, 1.0 \mathrm{mmol}), 1 \mathrm{H}$-benzo[d]imidazol-2-amine (5d, $146 \mathrm{mg}, 1.1 \mathrm{mmol})$, and DMAP (134 mg, $1.1 \mathrm{mmol})$ in DMF (3 mL) was added $\mathrm{EDC} \cdot \mathrm{HCl}(211 \mathrm{mg}, 1.1 \mathrm{mmol})$, and the mixture was stirred at RT for $24 \mathrm{~h}$. A total of $50 \mathrm{~mL}$ of water was added, and the resulting precipitate was filtered to give a solid, which was recrystallized from 1,4-dioxane to give compound $\mathbf{1 d}(136 \mathrm{mg}, 40 \%)$ as an off-white solid. Mp: $217{ }^{\circ} \mathrm{C}$ (decomposed). ${ }^{1} \mathrm{H}$ NMR (700 MHz, DMSO- $\left.d_{6}\right): \delta 0.63$ $(\mathrm{t}, J=7.0 \mathrm{~Hz}, 3 \mathrm{H}), 1.50-1.40(\mathrm{~m}, 2 \mathrm{H}), 2.27(\mathrm{t}, J=7.0 \mathrm{~Hz}, 2 \mathrm{H}), 4.14$ (s, 2H), $5.93(\mathrm{~s}, 1 \mathrm{H}), 7.05-7.09(\mathrm{~m}, 2 \mathrm{H}), 7.40-7.43(\mathrm{~m}, 2 \mathrm{H}), 12.10$ $(\mathrm{s}, 3 \mathrm{H}) .{ }^{13} \mathrm{C}$ NMR $\left(175 \mathrm{MHz}, \mathrm{DMSO}-d_{6}\right): \delta 13.3,20.5,34.5,38.4$, $106.5,111.5,114.1,120.3,121.0,136.3,146.7,161.6,162.3,163.9$, 167.7. HRMS (ESI+) calcd for $\mathrm{C}_{16} \mathrm{H}_{18} \mathrm{~N}_{5} \mathrm{O}_{2} \mathrm{~S}[\mathrm{M}+\mathrm{H}]^{+} 344.1176$. Found: $344.118(\Delta=-1.1 \mathrm{ppm})$.

$\mathrm{N}$-(4-Difluoromethoxyphenyl)-4-(4-oxo-6-propyl-1,4-dihydropyrimidin-2-ylthio)butanamide (2a). To a solution of thiouracil $7(0.85$ $\mathrm{g}, 5 \mathrm{mmol})$ and potassium carbonate $(1.03 \mathrm{~g}, 7.5 \mathrm{mmol})$ in methanol $(5 \mathrm{~mL})$ and water $(10 \mathrm{~mL})$ was added methyl 4-bromobutanoate $(1.36 \mathrm{~g}, 7.5 \mathrm{mmol})$. The solution was heated to reflux overnight. The reaction mixture was cooled to $\mathrm{RT}$ and $50 \mathrm{~mL}$ of water added, and the mixture was extracted with ethyl acetate $(3 \times 50 \mathrm{~mL})$. The organic layers were combined and washed with water $(50 \mathrm{~mL})$ and brine $(50$ $\mathrm{mL}$ ) and dried over $\mathrm{MgSO}_{4}$, the solvent was removed by rotary evaporator. The crude product was purified by flash column chromatography on silica gel using $\mathrm{MeOH} / \mathrm{DCM}$ as an eluent to give methyl 4-(4-oxo-6-propyl-1,4-dihydropyrimidin-2-ylthio)butanoate as a white solid (0.64 g, $47 \%$ yield). Mp: $129-130{ }^{\circ} \mathrm{C}$. ${ }^{1} \mathrm{H}$ NMR $\left(500 \mathrm{MHz}, \mathrm{CDCl}_{3}\right): \delta 0.95(\mathrm{t}, J=7.0 \mathrm{~Hz}, 3 \mathrm{H}), 1.64-$ $1.71(\mathrm{~m}, 2 \mathrm{H}), 2.06(\mathrm{~m}, 2 \mathrm{H}), 2.46(\mathrm{~m}, 4 \mathrm{H}), 3.24(\mathrm{t}, J=7.0 \mathrm{~Hz}, 2 \mathrm{H})$, $3.68(\mathrm{~s}, 3 \mathrm{H}), 6.04(\mathrm{~s}, 1 \mathrm{H}), 12.99(\mathrm{~s}, 1 \mathrm{H}) .{ }^{13} \mathrm{C}$ NMR $(125 \mathrm{MHz}$, $\left.\mathrm{CDCl}_{3}\right): \delta 13.8,21.0,24.7,29.9,32.7,39.7,51.8,108.0,160.2,165.6$, 169.5, 173.4. HRMS (ESI+) calcd for $\mathrm{C}_{12} \mathrm{H}_{19} \mathrm{~N}_{2} \mathrm{O}_{3} \mathrm{~S}[\mathrm{M}+\mathrm{H}]^{+}$: 271.1111. Found: $271.111(\Delta=0.51 \mathrm{ppm})$.

To a solution of methyl 4-(4-oxo-6-propyl-1,4-dihydropyrimidin-2ylthio)butanoate ( $500 \mathrm{mg}, 1.84 \mathrm{mmol})$ in $\mathrm{MeOH}$ and water was added lithium hydroxide $(88.1 \mathrm{mg}, 3.68 \mathrm{mmol})$, and the mixture was stirred at RT for 2 days. The mixture was adjusted to $\mathrm{pH} 1$ by $1 \mathrm{~N}$ hydrochloric acid to form a white precipitate. The precipitate was collected on a filter to afford 4-(4-oxo-6-propyl-1,4-dihydropyrimidin2 -ylthio)butanoic acid 9 as a white solid ( $308.0 \mathrm{mg}$, $66 \%$ yield). Mp: $139-141^{\circ} \mathrm{C} .{ }^{1} \mathrm{H}$ NMR $\left(300 \mathrm{MHz}, \mathrm{CDCl}_{3}\right): \delta 0.95(\mathrm{t}, J=7.3 \mathrm{~Hz}, 3 \mathrm{H})$, $1.68(\mathrm{~m}, 2 \mathrm{H}), 2.01-2.14(\mathrm{~m}, 2 \mathrm{H}), 2.49(\mathrm{~m}, 4 \mathrm{H}), 3.28(\mathrm{t}, J=6.5 \mathrm{~Hz}$, $2 \mathrm{H}), 6.04(\mathrm{~s}, 1 \mathrm{H}) .{ }^{13} \mathrm{C}$ NMR $\left(175 \mathrm{MHz} \mathrm{CDCl}_{3}\right): \delta 13.8,21.1,24.5$ $29.9,32.8,39.7,107.7,160.3,165.9,170.2,178.5$. HRMS (ESI+) calcd for $\mathrm{C}_{11} \mathrm{H}_{17} \mathrm{~N}_{2} \mathrm{O}_{3} \mathrm{~S}[\mathrm{M}+\mathrm{H}]^{+}:$257.0954. Found: $257.0958(\Delta=-1.33$ ppm).

To a mixture of $9(190 \mathrm{mg}, 0.74 \mathrm{mmol}), 4$-(difluoromethoxy)aniline (5a, $130.5 \mathrm{mg}, 0.82 \mathrm{mmol}$ ), and 4-(dimethylamino)pyridine (DMAP; $99.4 \mathrm{mg}, 0.81 \mathrm{mmol}$ ) in dimethylformamide (DMF; $3 \mathrm{~mL}$ ) was added $N^{\prime}$-ethylcarbodiimide hydrochloride (EDC $\cdot \mathrm{HCl}(156 \mathrm{mg}, 0.81$ $\mathrm{mmol})$ ); the mixture was stirred at RT for $1 \mathrm{~h}$. Then, $100 \mathrm{~mL}$ of water was added to the reaction mixture to form an off-white precipitate, which was collected on a filter to give an off-white solid. The solid was dissolved in ethyl acetate and dried over $\mathrm{MgSO}_{4}$ and filtered, and the solvent was removed by rotary evaporator. The crude product was purified by recrystallization from ethyl acetate/hexane to afford $2 \mathrm{a}$ as a white solid $(120.4 \mathrm{mg}, 41 \%$ yield $)$. Mp: $174-177^{\circ} \mathrm{C} .{ }^{1} \mathrm{H}$ $\operatorname{NMR}\left(500 \mathrm{MHz}, \mathrm{CDCl}_{3}\right): \delta 0.92(\mathrm{t}, J=7.5 \mathrm{~Hz}, 3 \mathrm{H}), 1.64(\mathrm{~m}, 2 \mathrm{H})$, $2.06-2.22(\mathrm{~m}, 2 \mathrm{H}), 2.42(\mathrm{t}, J=7.5 \mathrm{~Hz}, 2 \mathrm{H}), 2.49(\mathrm{t}, J=6.9 \mathrm{~Hz}, 2 \mathrm{H})$, $3.31(\mathrm{t}, J=5.7 \mathrm{~Hz}, 2 \mathrm{H}), 6.01(\mathrm{~s}, 1 \mathrm{H}), 6.45(\mathrm{t}, J=74.0 \mathrm{~Hz}, 1 \mathrm{H}), 7.07$ $(\mathrm{d}, J=8.6 \mathrm{~Hz}, 2 \mathrm{H}), 7.55(\mathrm{~d}, J=8.6 \mathrm{~Hz}, 2 \mathrm{H}), 7.92(\mathrm{~s}, 1 \mathrm{H}), 12.69(\mathrm{~s}$, 1H). ${ }^{13} \mathrm{C}$ NMR $\left(125 \mathrm{MHz}, \mathrm{CDCl}_{3}\right.$ ): $\delta 13.8,21.1,24.8,30.2,35.5,39.7$, $107.8,116.1(\mathrm{t}, J=259 \mathrm{~Hz}), 120.6,121.3,135.6,147.3,160.2,165.5$, $169.9,170.5 .{ }^{19} \mathrm{~F}$ NMR $\left(376 \mathrm{MHz}, \mathrm{CDCl}_{3}\right): \delta-80.7$. HRMS (ESI+) calcd for $\mathrm{C}_{18} \mathrm{H}_{22} \mathrm{~F}_{2} \mathrm{~N}_{3} \mathrm{O}_{3} \mathrm{~S}[\mathrm{M}+\mathrm{H}]^{+}$: 398.1344. Found: $398.1345(\Delta=$ $-0.03 \mathrm{ppm}$ ).

In the same manner, compound $2 \mathrm{c}$ was synthesized.

$\mathrm{N}$-(4-Fluorophenyl)-4-(4-oxo-6-propyl-1,4-dihydropyrimidin-2ylthio)butanamide (2c). White solid, $39 \%$ yield. Mp: $180-182{ }^{\circ} \mathrm{C} .{ }^{1} \mathrm{H}$ NMR $\left(300 \mathrm{MHz}, \mathrm{CDCl}_{3}\right): \delta 0.83-0.96(\mathrm{t}, J=7.3 \mathrm{~Hz}, 3 \mathrm{H}), 1.57-1.69$ $(\mathrm{m}, 2 \mathrm{H}), 2.05-2.21(\mathrm{~m}, 2 \mathrm{H}), 2.33-2.55(\mathrm{~m}, 4 \mathrm{H}), 3.31(\mathrm{t}, J=6.3 \mathrm{~Hz}$, $2 \mathrm{H}), 6.02(\mathrm{~s}, 1 \mathrm{H}), 7.00(\mathrm{t}, J=8.7 \mathrm{~Hz}, 2 \mathrm{H}), 7.49(\mathrm{~m}, 2 \mathrm{H}), 7.64(\mathrm{~s}, 1 \mathrm{H})$, $12.45(\mathrm{~s}, 1 \mathrm{H}) .{ }^{13} \mathrm{C}$ NMR $\left(175 \mathrm{MHz}, \mathrm{DMSO}-d_{6}\right): \delta 13.4,20.5,24.8$, 29.2, 34.9, 38.5, 115.2 (d, $J=22.0 \mathrm{~Hz}), 120.7$ (d, $J=7.7 \mathrm{~Hz}), 135.7$ (d, 
$J=2.3 \mathrm{~Hz}), 157.1,158.5,170.3 .{ }^{19} \mathrm{~F}$ NMR $\left(376 \mathrm{MHz} \mathrm{CDCl}_{3}\right): \delta$ -119.7. HRMS (ESI+) calcd for $\mathrm{C}_{17} \mathrm{H}_{21} \mathrm{FN}_{3} \mathrm{O}_{2} \mathrm{~S}[\mathrm{M}+\mathrm{H}]^{+}: 350.1333$. Found: $350.134(\Delta=-2.12 \mathrm{ppm})$.

4-(4-Oxo-3,4,5,6,7,8-hexahydroquinazolin-2-ylthio)-N-phenylbutanamide (3b). Ethyl 2-oxocyclohexane-1-carboxylate 10 (1.70 g, 10.0 $\mathrm{mmol})$ and thiourea $(1.52 \mathrm{~g}, 20.0 \mathrm{mmol})$ were added to a sodium methoxide solution ( $0.58 \mathrm{~g}$ sodium in $20 \mathrm{~mL}$ methanol), and the mixture was refluxed overnight. The solvent was removed, and the residue was dissolved in hot water $(50 \mathrm{~mL})$. Glacial acetic acid $(6 \mathrm{~mL})$ was added dropwise to make the solution acidic until a white solid was formed. The precipitate was collected by a filter and washed successively with saturated sodium bicarbonate $(3 \times 10 \mathrm{~mL})$ and water $(3 \times 10 \mathrm{~mL})$ and recrystallized from ethyl acetate $(30 \mathrm{~mL})$ to afford 2-sulfhydryl-5,6,7,8-tetrahydroquinazolin-4(3H)-one (11; 1.70 g, 93\%) as a white solid. $\mathrm{Mp}>230{ }^{\circ} \mathrm{C} .{ }^{1} \mathrm{H}$ NMR $(700 \mathrm{MHz}$, DMSOd6): $\delta 1.53-1.76(\mathrm{~m}, 4 \mathrm{H}), 2.16(\mathrm{t}, J=6.0 \mathrm{~Hz}, 2 \mathrm{H}), 2.36(\mathrm{t}, J=6.0 \mathrm{~Hz}$, $2 \mathrm{H}), 12.09(\mathrm{~s}, 1 \mathrm{H}), 12.25(\mathrm{~s}, 1 \mathrm{H}) \cdot{ }^{13} \mathrm{C}$ NMR (175 MHz, DMSO- $\left.d_{6}\right)$ : $\delta 20.5,20.7,20.9,25.5,111.6,149.5,161.3,173.9$. HRMS (ESI+) calcd for $\mathrm{C}_{8} \mathrm{H}_{11} \mathrm{~N}_{2} \mathrm{OS}[\mathrm{M}+\mathrm{H}]+$ : 183.0587. Found: $183.0587(\Delta=-0.44$ ppm).

To a solution of $11(1.59 \mathrm{~g}, 8.72 \mathrm{mmol})$ in anhydrous methanol (15 $\mathrm{mL}$ ) was added methyl 4-bromobutanoate $(1.72 \mathrm{~g}, 9.55 \mathrm{mmol})$ and potassium carbonate $(1.31 \mathrm{~g}, 9.48 \mathrm{mmol})$. The reaction mixture was heated to reflux overnight. After being cooled to RT, the reaction mixture was concentrated in vacuo to remove the solvent. To the residue was added water $(50 \mathrm{~mL})$, and it was extracted with dichloromethane $(4 \times 40 \mathrm{~mL})$. The combined organic phases were washed with brine $(5 \mathrm{~mL})$, dried over $\mathrm{MgSO}_{4}$, and concentrated in vacuo to give a crude product, which was purified by recrystallization from ethyl acetate to afford methyl 4-(4-oxo-3,4,5,6,7,8-hexahydroquinazolin-2-ylthio)butanoate $(1.80 \mathrm{~g}, 73 \%)$ as a white solid. Mp: $149-$ $150{ }^{\circ} \mathrm{C} .{ }^{1} \mathrm{H}$ NMR $\left(700 \mathrm{MHz}, \mathrm{CDCl}_{3}\right): \delta 1.69-1.79(\mathrm{~m}, 4 \mathrm{H}), 2.01-$ $2.06(\mathrm{~m}, 2 \mathrm{H}), 2.47(\mathrm{~m}, 4 \mathrm{H}), 2.59(\mathrm{t}, J=7.0 \mathrm{~Hz}, 2 \mathrm{H}), 3.22(\mathrm{t}, J=7.0$ $\mathrm{Hz}, 2 \mathrm{H}), 3.67(\mathrm{~s}, 3 \mathrm{H}) .{ }^{13} \mathrm{C} \mathrm{NMR}\left(175 \mathrm{MHz}, \mathrm{CDCl}_{3}\right): \delta 21.7,21.8$, $22.2,24.7,29.8,31.6,32.7,51.8,117.6,156.4,162.0,165.0,173.5$. HRMS (ESI+) calcd for $\mathrm{C}_{13} \mathrm{H}_{19} \mathrm{~N}_{2} \mathrm{O}_{3} \mathrm{~S}[\mathrm{M}+\mathrm{H}]^{+}$283.1111. Found: $283.1117(\Delta=-2.09 \mathrm{ppm})$.

To a mixture of $2 \mathrm{~N}$ sodium hydroxide $(1.51 \mathrm{~g}$ in $19 \mathrm{~mL}$ water) and ethanol $(22 \mathrm{~mL})$ was added methyl 4-(4-oxo-3,4,5,6,7,8-hexahydroquinazolin-2-ylthio)butanoate $(1.34 \mathrm{~g}, 4.75 \mathrm{mmol})$ at RT. The mixture was stirred overnight at $\mathrm{RT}$. The reaction mixture was adjusted to $\mathrm{pH}$ 5 with $1 \mathrm{~N}$ hydrochloric acid and extracted with dichloromethane $(5 \times$ $40 \mathrm{~mL}$ ). The combined organic phases were dried over $\mathrm{MgSO}_{4}$ and concentrated in vacuo to give a residue, which was recrystallized from dichloromethane to afford 4-(4-oxo-3,4,5,6,7,8-hexahydroquinazolin-2ylthio)butanoic acid 12 (1.26 g, 99\% yield) as a white solid. Mp: 176$177^{\circ} \mathrm{C} .{ }^{1} \mathrm{H}$ NMR $\left(700 \mathrm{MHz}, \mathrm{CD}_{3} \mathrm{OD}\right): \delta 1.71-1.81(\mathrm{~m}, 4 \mathrm{H}), 1.96-$ $2.03(\mathrm{~m}, 2 \mathrm{H}), 2.39(\mathrm{t}, J=6.3 \mathrm{~Hz}, 2 \mathrm{H}), 2.43(\mathrm{t}, J=7.0 \mathrm{~Hz}, 2 \mathrm{H}), 2.57(\mathrm{t}$, $J=6.3 \mathrm{~Hz}, 2 \mathrm{H}), 3.23(\mathrm{t}, J=7.0 \mathrm{~Hz}, 2 \mathrm{H}) .{ }^{13} \mathrm{C} \mathrm{NMR}(175 \mathrm{MHz}$, $\mathrm{CD}_{3} \mathrm{OD}$ ): $\delta$ 22.7, 22.9, 23.1, 26.0, 30.4, 33.4, 176.6. HRMS (ESI+) calcd for $\mathrm{C}_{12} \mathrm{H}_{17} \mathrm{~N}_{2} \mathrm{O}_{3} \mathrm{~S}[\mathrm{M}+\mathrm{H}]^{+}$: 269.0954. Found: $269.0959(\Delta=$ $-1.54 \mathrm{ppm})$.

To a mixture of thiobutanoic acid $12(134 \mathrm{mg}, 0.50 \mathrm{mmol})$, aniline 5 b $(70 \mathrm{mg}, 0.75 \mathrm{mmol})$, and DMAP $(67 \mathrm{mg}, 0.55 \mathrm{mmol})$ in DMF (2 $\mathrm{mL})$ was added EDC. $\mathrm{HCl}(105 \mathrm{mg}, 0.55 \mathrm{mmol})$, and the mixture was stirred at RT for $48 \mathrm{~h}$. To the reaction mixture was added $50 \mathrm{~mL}$ of water with stirring to form a precipitate. The resulting precipitate was collected on a filter and recrystallized from ethyl acetate to give $\mathbf{3 b}$ (79 $\mathrm{mg}, 46 \%$ yield) as an off-white solid. Mp: $193-194{ }^{\circ} \mathrm{C} .{ }^{1} \mathrm{H}$ NMR (500 MHz, DMSO- $\left.d_{6}\right): \delta 1.56-1.67(\mathrm{~m}, 4 \mathrm{H}), 1.91-1.97(\mathrm{~m}, 2 \mathrm{H}), 2.26(\mathrm{~m}$, $2 \mathrm{H}), 2.39-2.45(\mathrm{~m}, 4 \mathrm{H}), 3.16(\mathrm{t}, J=7.0 \mathrm{~Hz}, 2 \mathrm{H}), 7.01(\mathrm{t}, J=8.0 \mathrm{~Hz}$, $1 \mathrm{H}), 7.27(\mathrm{t}, J=8.0 \mathrm{~Hz}, 2 \mathrm{H}), 7.58(\mathrm{~d}, J=8.0 \mathrm{~Hz}, 2 \mathrm{H}), 9.90(\mathrm{~s}, 1 \mathrm{H})$, $12.42(\mathrm{~s}, 1 \mathrm{H}) .{ }^{13} \mathrm{C}$ NMR $\left(125 \mathrm{MHz}, \mathrm{DMSO}-d_{6}\right): \delta 21.4,21.8,24.7$, 29.0, 31.1, 34.9, 119.0, 122.9, 128.6, 139.3, 170.3. HRMS (ESI+) Calcd for $\mathrm{C}_{18} \mathrm{H}_{22} \mathrm{~N}_{3} \mathrm{O}_{2} \mathrm{~S}[\mathrm{M}+\mathrm{H}]^{+}:$344.1427. Found: $344.1430(\Delta=-0.71$ ppm).

In the same manner, compounds $\mathbf{3 a} \mathbf{a} \mathbf{3} \mathbf{c}$, and $\mathbf{3 d}$ were synthesized. $\mathrm{N}$-(4-Difluoromethoxyphenyl)-4-(4-oxo-3,4,5,6,7,8-hexahydroquinazolin-2-y/thio)butanamide (3a). Off-white solid, $52 \%$ yield. Mp: $197-198{ }^{\circ} \mathrm{C} .{ }^{1} \mathrm{H}$ NMR $\left(700 \mathrm{MHz}\right.$, acetone- $\left.d_{6}\right): \delta 1.63-1.73(\mathrm{~m}$,
$4 \mathrm{H}), 2.09(\mathrm{~m}, 2 \mathrm{H}), 2.35(\mathrm{t}, J=6.3 \mathrm{~Hz}, 2 \mathrm{H}), 2.47(\mathrm{t}, J=6.3 \mathrm{~Hz}, 2 \mathrm{H})$ $2.53(\mathrm{t}, J=7.0 \mathrm{~Hz}, 2 \mathrm{H}), 3.27(\mathrm{t}, J=7.0 \mathrm{~Hz}, 2 \mathrm{H}), 6.90(\mathrm{t}, J=74.4 \mathrm{~Hz}$, $1 \mathrm{H}), 7.11(\mathrm{~d}, J=8.4 \mathrm{~Hz}, 2 \mathrm{H}), 7.70(\mathrm{~d}, J=8.4 \mathrm{~Hz}, 2 \mathrm{H}), 9.27(\mathrm{~s}, 1 \mathrm{H})$, $11.46(\mathrm{~s}, 1 \mathrm{H}) .{ }^{13} \mathrm{C}$ NMR $\left(175 \mathrm{MHz}\right.$, acetone- $\left.d_{6}\right): \delta 22.4,22.5,23.0$, $26.0,32.2,35.9,117.6(\mathrm{t}, J=255.5 \mathrm{~Hz}), 117.9,120.6,121.3,137.9$, $147.6(\mathrm{t}, J=2.6 \mathrm{~Hz}), 157.2,161.2,163.4,171.2 .{ }^{19} \mathrm{~F}$ NMR $(376 \mathrm{MHz}$, acetone- $\left.d_{6}\right): \delta-82.3$. HRMS (ESI+) Calcd for $\mathrm{C}_{19} \mathrm{H}_{22} \mathrm{~F}_{2} \mathrm{~N}_{3} \mathrm{O}_{3} \mathrm{~S}[\mathrm{M}+$ $\mathrm{H}]^{+}$: 410.1344. Found: $410.1346(\Delta=-0.33 \mathrm{ppm})$.

$\mathrm{N}$-(4-Fluorophenyl)-4-(4-oxo-3,4,5,6,7,8-hexahydroquinazolin-2ylthio)butanamide (3c). White solid, $70 \%$ yield. Mp: $211.5-213{ }^{\circ} \mathrm{C}$. ${ }^{1} \mathrm{H}$ NMR $\left(700 \mathrm{MHz}\right.$, DMSO- $\left.d_{6}\right): \delta 1.56-1.66(\mathrm{~m}, 4 \mathrm{H}), 1.94(\mathrm{~m}, 2 \mathrm{H})$, $2.26(\mathrm{t}, J=5.6 \mathrm{~Hz}, 2 \mathrm{H}), 2.41(\mathrm{t}, J=7.0 \mathrm{~Hz}, 4 \mathrm{H}), 3.15(\mathrm{t}, J=7.0 \mathrm{~Hz}$, $2 \mathrm{H}), 7.10-7.14(\mathrm{~m}, 2 \mathrm{H}), 7.57-7.61(\mathrm{~m}, 2 \mathrm{H}), 9.96(\mathrm{~s}, 1 \mathrm{H}), 12.44(\mathrm{~s}$, 1H). ${ }^{13} \mathrm{C}$ NMR (175 MHz, DMSO- $\left.d_{6}\right): \delta 21.4,21.8,24.7,29.0,31.1$, $34.8,115.2(\mathrm{~d}, J=21.9 \mathrm{~Hz}), 120.7(\mathrm{~d}, J=7.7 \mathrm{~Hz}), 135.7(\mathrm{~d}, J=2.3$ $\mathrm{Hz}), 157.8(\mathrm{~d}, J=238 \mathrm{~Hz}), 170.3 .{ }^{19} \mathrm{~F}$ NMR $\left(376 \mathrm{MHz}\right.$, DMSO- $\left.d_{6}\right): \delta$ -119.8 . HRMS (ESI+) calcd for $\mathrm{C}_{18} \mathrm{H}_{21} \mathrm{FN}_{3} \mathrm{O}_{2} \mathrm{~S}[\mathrm{M}+\mathrm{H}]^{+}: 362.1333$. Found: $362.1337(\Delta=-1.05 \mathrm{ppm})$.

$\mathrm{N}$-(1H-Benzo[d]imidazol-2-yl)-4-(4-oxo-3,4,5,6,7,8-hexahydroquinazolin-2-ylthio)butanamide (3d). Off-white solid, $22 \%$ yield. $\mathrm{Mp}>$ $230{ }^{\circ} \mathrm{C} .{ }^{1} \mathrm{H}$ NMR $\left(700 \mathrm{MHz}, \mathrm{DMSO}-d_{6}\right): \delta 1.55-1.66(\mathrm{~m}, 4 \mathrm{H}), 2.09$ $(\mathrm{m}, 2 \mathrm{H}), 2.21-2.27(\mathrm{~m}, 2 \mathrm{H}), 2.35-2.41(\mathrm{~m}, 2 \mathrm{H}), 3.21(\mathrm{t}, J=5.6 \mathrm{~Hz}$, $2 \mathrm{H}), 3.27(\mathrm{t}, J=5.6 \mathrm{~Hz}, 2 \mathrm{H}), 6.93(\mathrm{t}, J=7.0 \mathrm{~Hz}, 1 \mathrm{H}), 7.11-7.22(\mathrm{~m}$, $2 \mathrm{H}), 7.38-7.48(\mathrm{~m}, 3 \mathrm{H}), 12.45(\mathrm{~s}, 1 \mathrm{H}) .{ }^{13} \mathrm{C}$ NMR $(125 \mathrm{MHz}$, DMSO- $\left.d_{6}\right): \delta 21.4,21.8,23.7,28.5,31.0,36.2,113.6,115.7,116.4$, $119.5,124.1,130.0,143.4,154.6,156.5,160.0,162.4,173.8$. HRMS (ESI+) Calcd for $\mathrm{C}_{19} \mathrm{H}_{22} \mathrm{~N}_{5} \mathrm{O}_{2} \mathrm{~S}[\mathrm{M}+\mathrm{H}]^{+}:$384.1489. Found: $384.1494(\Delta=-1.45 \mathrm{ppm})$.

4-(4-Oxo-3,4-dihydroquinazolin-2-ylthio)-N-phenylbutanamide (4b). A mixture of 2-sulfhydrylquinazolin-4(3H)-one $(13 ; 1.78 \mathrm{~g}, 10.0$ mmol), methyl 4-bromobutanoate $(2.72 \mathrm{~g}, 15.0 \mathrm{mmol})$, and $\mathrm{K}_{2} \mathrm{CO}_{3}$ $(2.07 \mathrm{~g}, 15.0 \mathrm{mmol})$ in methanol $(10 \mathrm{~mL})$ and water $(20 \mathrm{~mL})$ was refluxed for $1 \mathrm{~h}$. After being cooled to RT, $50 \mathrm{~mL}$ of water was added, and the reaction mixture was extracted with ethyl acetate $(3 \times 50 \mathrm{~mL})$. The combined organic layers were washed with water $(50 \mathrm{~mL})$ and brine $(50 \mathrm{~mL})$, dried over $\mathrm{MgSO}_{4}$, and concentrated in vacuo to give a crude product, which was purified by recrystallization from ethyl acetate/hexanes to give methyl 4-(4-oxo-3,4-dihydroquinazolin-2ylthio)butanoate $(2.24 \mathrm{~g}, 81 \%$ yield) as a white solid. Mp: $153-154$ ${ }^{\circ} \mathrm{C} .{ }^{1} \mathrm{H}$ NMR $\left(700 \mathrm{MHz}, \mathrm{DMSO}-d_{6}\right): \delta 1.96(\mathrm{~m}, 2 \mathrm{H}), 2.45(\mathrm{t}, J=7.0$ $\mathrm{Hz}, 2 \mathrm{H}), 3.23(\mathrm{t}, J=7.0 \mathrm{~Hz}, 2 \mathrm{H}), 3.58(\mathrm{~s}, 3 \mathrm{H}), 7.39(\mathrm{t}, J=7.0 \mathrm{~Hz}$, $1 \mathrm{H}), 7.49$ (d, $J=7.0 \mathrm{~Hz}, 1 \mathrm{H}), 7.73(\mathrm{t}, J=7.0 \mathrm{~Hz}, 1 \mathrm{H}), 8.02$ (d, $J=7.0$ $\mathrm{Hz}, 1 \mathrm{H}), 12.55(\mathrm{~s}, 1 \mathrm{H}) .{ }^{13} \mathrm{C}$ NMR $\left(175 \mathrm{MHz}, \mathrm{DMSO}-d_{6}\right): \delta 24.3$, 28.9, 32.1, 51.4, 120.0, 125.6, 125.9, 126.0, 134.5, 148.3, 155.5, 161.3, 172.8. HRMS (ESI+) Calcd for $\mathrm{C}_{13} \mathrm{H}_{15} \mathrm{~N}_{2} \mathrm{O}_{3} \mathrm{~S}[\mathrm{M}+\mathrm{H}]^{+}$: 279.0798 . Found: $279.0802(\Delta=-1.42 \mathrm{ppm})$.

A mixture of methyl 4-(4-oxo-3,4-dihydroquinazolin-2-ylthio)butanoate $(1.39 \mathrm{~g}, 5.0 \mathrm{mmol})$ in DMSO $(1 \mathrm{~mL})$ and $\mathrm{LiOH}$ (aqueous, $1 \mathrm{M}, 10 \mathrm{~mL}$ ) was stirred at RT for $2 \mathrm{~h}$. To the reaction mixture was added $100 \mathrm{~mL}$ of water, and it was adjusted to $\mathrm{pH} 1$. The resulting precipitate was collected on a filter and washed with water to give 4-(4oxo-3,4-dihydroquinazolin-2-ylthio)butanoic acid (14; $1.14 \mathrm{~g}, 86 \%$ yield) as a white solid. Mp: $178-179{ }^{\circ} \mathrm{C} .{ }^{1} \mathrm{H}$ NMR $(500 \mathrm{MHz}$, DMSO- $\left.d_{6}\right): \delta 1.90-1.96(\mathrm{~m}, 2 \mathrm{H}), 2.37(\mathrm{t}, J=7.0 \mathrm{~Hz}, 2 \mathrm{H}), 3.24(\mathrm{t}, J=$ $7.0 \mathrm{~Hz}, 2 \mathrm{H}), 7.41(\mathrm{t}, J=7.5 \mathrm{~Hz}, 1 \mathrm{H}), 7.52(\mathrm{~d}, J=7.5 \mathrm{~Hz}, 1 \mathrm{H}), 7.75(\mathrm{t}$, $J=7.5 \mathrm{~Hz}, 1 \mathrm{H}), 8.02(\mathrm{~d}, J=7.5 \mathrm{~Hz}, 1 \mathrm{H}), 12.37(\mathrm{~s}, 2 \mathrm{H}) .{ }^{13} \mathrm{C} \mathrm{NMR}$ $\left(175 \mathrm{MHz}, \mathrm{DMSO}-d_{6}\right): \delta 24.3,29.1,32.5,120.0,125.6,125.9,126.0$, 134.6, 148.3, 155.6, 161.3,173.9. HRMS (ESI+) Calcd for $\mathrm{C}_{12} \mathrm{H}_{13} \mathrm{~N}_{2} \mathrm{O}_{3} \mathrm{~S}[\mathrm{M}+\mathrm{H}]^{+}:$265.0641. Found: $265.0646(\Delta=-1.56$ $\mathrm{ppm})$.

To a mixture of 4-(4-oxo-3,4-dihydroquinazolin-2-ylthio)butanoic acid (14; $132 \mathrm{mg}, 0.50 \mathrm{mmol})$, aniline $(186 \mathrm{mg}, 2.0 \mathrm{mmol})$, and DMAP $(67 \mathrm{mg}, 0.55 \mathrm{mmol})$ in DMF $(2 \mathrm{~mL})$ was added EDC $\cdot \mathrm{HCl}$ $(144 \mathrm{mg}, 0.75 \mathrm{mmol})$, and the mixture was stirred at RT for $18 \mathrm{~h}$. To the reaction mixture was added $20 \mathrm{~mL}$ of water with stirring. The resulting precipitate was collected on a filter and recrystallized from 1,4-dioxane to give $4 \mathbf{b}(61 \mathrm{mg}, 36 \%$ yield) as a white solid. Mp: $>230$ ${ }^{\circ} \mathrm{C} .{ }^{1} \mathrm{H}$ NMR $\left(700 \mathrm{MHz}\right.$, DMSO- $\left.d_{6}\right): \delta 1.56-1.60(\mathrm{~m}, 2 \mathrm{H}), 2.03(\mathrm{t}, J$ $=7.0 \mathrm{~Hz}, 2 \mathrm{H}), 2.84(\mathrm{t}, J=7.0 \mathrm{~Hz}, 2 \mathrm{H}), 6.57(\mathrm{t}, J=7.0 \mathrm{~Hz}, 1 \mathrm{H}), 6.83$ $(\mathrm{t}, J=7.0 \mathrm{~Hz}, 2 \mathrm{H}), 6.95(\mathrm{t}, J=7.0 \mathrm{~Hz}, 1 \mathrm{H}), 7.01(\mathrm{~d}, J=8.4 \mathrm{~Hz}, 1 \mathrm{H})$, 
$7.13(\mathrm{~d}, J=7.0 \mathrm{~Hz}, 2 \mathrm{H}), 7.25(\mathrm{t}, J=7.0 \mathrm{~Hz}, 1 \mathrm{H}), 7.57(\mathrm{~d}, J=7.0 \mathrm{~Hz}$, $1 \mathrm{H}), 9.48(\mathrm{~s}, 1 \mathrm{H}), 12.12(\mathrm{~s}, 1 \mathrm{H}) \cdot{ }^{13} \mathrm{C}$ NMR $\left(175 \mathrm{MHz}, \mathrm{DMSO}-d_{6}\right): \delta$ $24.8,29.2,35.1,119.0,112.0,123.0,125.6,126.0,128.6,134.5,139.3$, 148.4, 155.6, 161.2, 170.4. HRMS (ESI+) Calcd for $\mathrm{C}_{18} \mathrm{H}_{18} \mathrm{~N}_{3} \mathrm{O}_{2} \mathrm{~S}[\mathrm{M}$ $+\mathrm{H}]^{+}$: 340.1114. Found: $340.1121(\Delta=-2.0 \mathrm{ppm})$.

In the same manner, compounds $4 \mathbf{a}, \mathbf{4 c}$, and $4 \mathrm{~d}$ were synthesized. $\mathrm{N}$-(4-(Difluoromethoxy)phenyl)-4-(4-oxo-3,4-dihydroquinazolin2-ylthio)butanamide (4a). Off-white solid, $42 \%$ yield. Mp: $210-211$ ${ }^{\circ} \mathrm{C} .{ }^{1} \mathrm{H}$ NMR $\left(700 \mathrm{MHz}\right.$, acetone- $\left.d_{6}\right): \delta 2.13-2.23(\mathrm{~m}, 2 \mathrm{H}), 2.59(\mathrm{t}, J$ $=7.0 \mathrm{~Hz}, 2 \mathrm{H}), 3.41(\mathrm{t}, J=7.0 \mathrm{~Hz}, 2 \mathrm{H}), 6.90(\mathrm{t}, J=74.2 \mathrm{~Hz}, 1 \mathrm{H}), 7.11$ $(\mathrm{d}, J=8.4 \mathrm{~Hz}, 2 \mathrm{H}), 7.40(\mathrm{t}, J=7.7 \mathrm{~Hz}, 1 \mathrm{H}), 7.49(\mathrm{~d}, J=7.7 \mathrm{~Hz}, 1 \mathrm{H})$, $7.69(\mathrm{~m}, 3 \mathrm{H}), 8.09(\mathrm{~d}, \mathrm{~J}=7.7 \mathrm{~Hz}, 1 \mathrm{H}), 9.25(\mathrm{~s}, 1 \mathrm{H}), 11.22(\mathrm{~s}, 1 \mathrm{H})$. ${ }^{13} \mathrm{C}$ NMR (175 MHz, DMSO- $\left.d_{6}\right): \delta 24.7,29.2,34.9,116.5(\mathrm{t}, J=256$ $\mathrm{Hz}), 119.5,120.0,120.4,125.6$, 126.0, 134.5, 136.7, 146.1, 148.40, 155.6, 161.3, 170.4. ${ }^{19} \mathrm{~F}$ NMR (376 MHz, DMSO- $\left.d_{6}\right): \delta-81.4$. HRMS (ESI+) Calcd for $\mathrm{C}_{19} \mathrm{H}_{18} \mathrm{~F}_{2} \mathrm{~N}_{3} \mathrm{O}_{3} \mathrm{~S}[\mathrm{M}+\mathrm{H}]^{+}:$406.1031. Found: $406.1033(\Delta=-0.44 \mathrm{ppm})$.

$\mathrm{N}$-(4-Fluorophenyl)-4-((4-oxo-3,4-dihydroquinazolin-2-yl)thio)butanamide (4c). White solid, $46 \%$ yield. Mp: $216-217^{\circ} \mathrm{C}$. ${ }^{1} \mathrm{H}$ NMR $\left(500 \mathrm{MHz}, \mathrm{DMSO}-d_{6}\right): \delta 1.20-2.05(\mathrm{~m}, 2 \mathrm{H}), 2.47(\mathrm{t}, J=7.0 \mathrm{~Hz}, 2 \mathrm{H})$, $3.29(\mathrm{t}, J=7.0 \mathrm{~Hz}, 2 \mathrm{H}), 7.09-7.14(\mathrm{~m}, 2 \mathrm{H}), 7.38-7.41(\mathrm{~m}, 1 \mathrm{H}), 7.45$ $(\mathrm{d}, J=8.0 \mathrm{~Hz}, 1 \mathrm{H}), 7.57-7.60(\mathrm{~m}, 2 \mathrm{H}), 7.68-7.72(\mathrm{~m}, 1 \mathrm{H}), 8.02(\mathrm{dd}$, $J=8.0,1.5 \mathrm{~Hz}, 1 \mathrm{H}), 9.97(\mathrm{~s}, 1 \mathrm{H}), 12.56(\mathrm{~s}, 1 \mathrm{H}) .{ }^{13} \mathrm{C}$ NMR $(125 \mathrm{MHz}$, DMSO- $\left.d_{6}\right): \delta 24.7,29.2,34.9,115.2(\mathrm{~d}, J=21.9 \mathrm{~Hz}), 112.0,120.7(\mathrm{~d}, J$ $=7.7 \mathrm{~Hz}), 125.6,126.0,126.0,134.5,135.7(\mathrm{~d}, J=2.4 \mathrm{~Hz}), 148.4$, $155.5,157.8(\mathrm{~d}, J=237.9 \mathrm{~Hz}), 161.2,170.3 .{ }^{19} \mathrm{~F}$ NMR $(376 \mathrm{MHz}$, DMSO- $d_{6}$ ): $\delta-119.8$. HRMS (ESI+) Calcd for $\mathrm{C}_{18} \mathrm{H}_{17} \mathrm{FN}_{3} \mathrm{O}_{2} \mathrm{~S}[\mathrm{M}+$ $\mathrm{H}]^{+}$358.1020. Found: $358.1027(\Delta=-1.99 \mathrm{ppm})$.

$\mathrm{N}$-(1H-Benzo[d]imidazol-2-yl)-4-(4-oxo-3,4-dihydroquinazolin-2ylthio)butanamide (4d). White solid, $25 \%$ yield. Mp $>230{ }^{\circ} \mathrm{C} .{ }^{1} \mathrm{H}$ NMR (700 MHz, DMSO- $\left.d_{6}\right): \delta 2.05-2.09(\mathrm{~m}, 2 \mathrm{H}), 2.61(\mathrm{t}, J=7.0$ $\mathrm{Hz}, 2 \mathrm{H}), 3.31(\mathrm{t}, J=7.0 \mathrm{~Hz}, 2 \mathrm{H}), 7.07(\mathrm{~m}, 2 \mathrm{H}), 7.33-7.50(\mathrm{~m}, 4 \mathrm{H})$, $7.58(\mathrm{t}, J=7.0 \mathrm{~Hz}, 1 \mathrm{H}), 8.00(\mathrm{~d}, J=7.0 \mathrm{~Hz}, 1 \mathrm{H}), 11.52(\mathrm{~s}, 1 \mathrm{H}), 12.06$ $(\mathrm{s}, 1 \mathrm{H}), 12.57(\mathrm{~s}, 1 \mathrm{H}) .{ }^{13} \mathrm{C}$ NMR $\left(175 \mathrm{MHz}\right.$, DMSO- $\left.d_{6}\right): \delta 24.5,29.0$, $31.1,111.5,116.9,120.0,121.8,125.5,126.0,132.5,134.4,140.5$, 146.6, 148.4, 155.6, 161.3, 171.8. HRMS (ESI+) Calcd for $\mathrm{C}_{19} \mathrm{H}_{17} \mathrm{~N}_{5} \mathrm{O}_{2} \mathrm{~S}[\mathrm{M}+\mathrm{H}]^{+}$: 380.1176. Found: $380.1178(\Delta=-0.54$ ppm).

N-Hexyl-4-(4-oxo-3,4-dihydroquinazolin-2-ylthio)butanamide (4e). To a mixture of 4-(4-oxo-3,4-dihydroquinazolin-2-ylthio)butanoic acid $(14 ; 79 \mathrm{mg}, 0.30 \mathrm{mmol})$ in 1,4-dioxane $(2 \mathrm{~mL})$ was added carbonyldiimidazole (CDI; $73 \mathrm{mg}, 0.45 \mathrm{mmol}$ ), and the mixture was stirred at RT for $1 \mathrm{~h}$. 1-Hexylamine $(5 \mathrm{e}, 61 \mathrm{mg}, 0.60 \mathrm{mmol})$ and DMF $(5 \mathrm{~mL})$ were added to the mixture and heated at $60^{\circ} \mathrm{C}$ for $48 \mathrm{~h}$. After being cooled to RT, $40 \mathrm{~mL}$ of water was added, and the reaction mixture was extracted with EtOAc $(3 \times 20 \mathrm{~mL})$. The combined organic layers were washed with water $(20 \mathrm{~mL})$ and brine $(20 \mathrm{~mL})$, dried over $\mathrm{MgSO}_{4}$, and concentrated in vacuo to give a yellow oil. Then, $20 \mathrm{~mL}$ of hexane was added to this oil with stirring to form a precipitate. The resulting precipitate was collected on a filter to give $4 \mathrm{e}$ (46.7 mg, $45 \%$ yield) as a white solid. Mp: $168-169{ }^{\circ} \mathrm{C} .{ }^{1} \mathrm{H}$ NMR $\left(700 \mathrm{MHz}, \mathrm{DMSO}-d_{6}\right): \delta 0.81(\mathrm{t}, J=5.6 \mathrm{~Hz}, 3 \mathrm{H}), 1.20(\mathrm{~m}, 6 \mathrm{H}), 1.35$ $(\mathrm{m}, 2 \mathrm{H}), 1.92(\mathrm{~m}, 2 \mathrm{H}), 2.22(\mathrm{t}, J=7.0 \mathrm{~Hz}, 2 \mathrm{H}), 3.01(\mathrm{~m}, 2 \mathrm{H}), 3.20(\mathrm{t}$, $J=7.0 \mathrm{~Hz}, 2 \mathrm{H}), 7.40(\mathrm{t}, J=7.7 \mathrm{~Hz}, 1 \mathrm{H}), 7.49(\mathrm{~d}, J=7.7 \mathrm{~Hz}, 1 \mathrm{H}), 7.73$ $(\mathrm{t}, J=7.7 \mathrm{~Hz}, 1 \mathrm{H}), 7.82(\mathrm{~s}, 1 \mathrm{H}), 8.02(\mathrm{~d}, J=7.7 \mathrm{~Hz}, 1 \mathrm{H}), 12.55(\mathrm{~s}$, $1 \mathrm{H}) .{ }^{13} \mathrm{C}$ NMR $\left(175 \mathrm{MHz}, \mathrm{DMSO}-d_{6}\right): \delta 13.9,22.1,25.0,26.1,29.1$, 29.3, 31.0, 34.2, 38.5, 120.0, 125.5, 125.9, 126.0, 134.5, 148.4, 155.7, 161.3, 171.0. HRMS (ESI+) Calcd for $\mathrm{C}_{18} \mathrm{H}_{26} \mathrm{~N}_{3} \mathrm{O}_{2} \mathrm{~S}[\mathrm{M}+\mathrm{H}]^{+}$: 348.1740. Found: $348.1742(\Delta=-0.54 \mathrm{ppm})$.

Cell Culture and Transfection. COS-1 monkey epithelial, human fibrosarcoma HT-1080, and breast MCF-7 cancer cell lines were purchased from American Type Culture Collection (ATCC) and were maintained in Dulbecco's modified Eagle medium (DMEM; Invitrogen) containing $10 \%$ fetal calf serum under a $5 \% \quad \mathrm{CO}_{2}$ atmosphere. Transfection of plasmid DNA (human) into cells was achieved using polyethylenimine (Polysciences), and the transfected cells were incubated for $48 \mathrm{~h}$ at $37^{\circ} \mathrm{C}$ followed by biochemical and biologic assays unless otherwise stated.

Two-Dimensional Dot Migration Assay. Transfected cells were mixed with an equal volume of neutralized type I collagen $(3 \mathrm{mg}$
$\left.\mathrm{mL}^{-1}\right)$ on ice. The cell-collagen mixture $\left(1 \mu \mathrm{L}\right.$ of $1 \times 10^{7}$ cell $\left./ \mathrm{mL}\right)$ was then dotted onto a 96-well plate. After solidification of cellcollagen dots, the cell-collagen hemispheres were covered with 100 $\mu \mathrm{L}$ of complete media and incubated for $8-18 \mathrm{~h}$ (incubation time varies by cell type), followed by staining with DAPI nuclear dye and counting of the migrated cells using a Nikon Elements Basic Research Software analysis tools. ${ }^{50}$

Co-immunoprecipitation. Twenty-four hours following transfection, the conditioned medium in the absence of serum was collected from the transfected HT1080 cells. The cells were then lysed in RIPA buffer containing $10 \mathrm{mM}$ Tris-Cl ( $\mathrm{pH} 8.0$ ), $1 \mathrm{mM}$ EDTA, 1\% Triton $\mathrm{X}-100,0.1 \%$ sodium deoxycholate, $0.1 \%$ SDS, $140 \mathrm{mM} \mathrm{NaCl}$, and a protease inhibitors mixture (Sigma). Both the conditioned medium and the cell lysates were incubated with specific antibodies overnight $(18 \mathrm{~h})$ at $4{ }^{\circ} \mathrm{C}$. Antigen antibody complexes were precipitated with protein A-agarose beads followed by a brief centrifugation, washing, and then electrophoresis in a $10 \%$ SDS-polyacrylamide gel. Western blotting was then followed using a corresponding antibody as previously described. ${ }^{12}$

Immunofluorescence. Cultured cells were fixed with $4 \%$ paraformaldehyde/phosphate-buffered saline (PBS) followed by blocking with $5 \%$ bovine serum albumin (BSA)/PBS. Both FAK and PAX were detected with an anti-p-FAK ${ }^{\mathrm{Tyr}} 576 / 577$ and anti-p-PAX ${ }^{\mathrm{Tyr} 118}$ antibody followed by secondary antibodies conjugated with antirabbit Alexa 568 or Alexa 488, respectively (Invitrogen). For colocalization experiments, MMP-9 was detected with an anti-MMP-9 antibody followed by a secondary antibody conjugated with antirabbit Alexa 488 , while $\alpha 4$ and $\beta 1$ integrins were detected with an anti- $\alpha 4$ integrin and anti- $\beta 1$ integrin, respectively, followed by a secondary antibody conjugated with antimouse Alexa 568. Nuclei were counterstained with DAPI (Invitrogen). Images were captured using a Zeiss LSM 510 META NLO Two-Photon Laser Scanning Confocal Microscope System (Central Microscopy Imaging Center, Stony Brook University).

Fluorogenic Assay of Enzyme Activity. Mca-PLGL-Dpa-AR$\mathrm{NH}_{2}$ fluorogenic peptide substrate (final concentration of $10 \mu \mathrm{M}$ in DMSO) was incubated with the compounds and $p$-aminophenylmercuric acetate (APMA)-activated proMMP-9 for $30 \mathrm{~min}$ at $25^{\circ} \mathrm{C}$ before detection. Fluorescence emission at $405 \mathrm{~nm}$ with excitation at $320 \mathrm{~nm}$ was measured in a fluorescent plate reader (Gemini EM; Molecular Devices). ${ }^{51}$

Cell Viability. HT1080 cells were cultured in complete media with or without compound 3c. Media and drugs were changed on a bidaily basis, and cell viability was monitored by MTT assay [3-(4,5dimethylthiazol-2-yl)-2,5-diphenyltetrazolium bromide] (Promega, Madison, WI). Each day, cells were exposed to MTT and incubated at $37^{\circ} \mathrm{C}$ for $4 \mathrm{~h}$. The reaction was stopped, and formazan crystals were solubilized; the resultant solution was subject to colorimetric spectrophotometry and read at a wavelength of $570 \mathrm{~nm} .^{52}$

Chorioallantoic Membrane Angiogenesis and Invasion Assay. The chorioallantoic membrane (CAM) assay was performed as previously described. ${ }^{53}$ Fertilized white chicken eggs (SPF Premium, Charles River Laboratory, North Franklin, CT) were incubated at $37{ }^{\circ} \mathrm{C}$ in $70 \%$ humidity for 3 days. The embryos were then incubated ex ovo in a sterile Petri dish for 7 days. Gelatin sponges adsorbed with HT1080 cells treated with or without compound 3c were implanted on the CAM surface, and neovasculature was counted on day 4 postimplantation. ${ }^{54,55}$ For histochemical analysis of the chorioallantoic membrane, embryos were treated as for the angiogenesis assay, except at day 10 the embryos were inoculated with pretreated HT1080 cells mixed with a type IV collagen solution (3 mg $\left.\mathrm{mL}^{-1}\right)$. After a 7-day incubation, CAM segments containing the cell dot collagen mixture were isolated, formalin fixed, and sectioned by microtome into 6- $\mu \mathrm{m}$ sections after embedding in OCT. Sections were then stained with hematoxylin and counterstained with eosin. ${ }^{56}$

proMMP-9 Protein Purification. For purification of proMMP-2 and proMMP-9 protein, COS-1 cells stably expressing each respective MMP were incubated overnight in $10 \mathrm{~mL}$ of serum-free medium until $500 \mathrm{~mL}$ was collected for purification via a gelatin-sepharose column. Both proMMP-2 and proMMP-9 have three fibronectin repeats 
present in their gelatin binding domain, which allowed us to capture and collect the secreted protein present in the serum-free medium fraction. Protein was then eluted off the gelatin sepharose column using 5\% DMSO and then dialyzed to remove any organic contaminants. A coomassie blue gel was then run to check the purity of the samples to ensure no protein contamination was present in the final solution. All methods were followed as previously described. ${ }^{57}$

Fluorescence Spectroscopy. Binding of compound $3 \mathrm{c}$ to proMMP-9 was assayed by observing the change of tryptophan emission upon binding. Purified recombinant proMMP-9 $(0.5 \mu \mathrm{M})$ or MMP-9/MMP-2PEX $(0.5 \mu \mathrm{M})$ was diluted in TNC buffer $(50 \mathrm{mM}$ Tris- $\mathrm{HCl}$ at $\mathrm{pH} 7.5,150 \mathrm{nM} \mathrm{NaCl}, 10 \mathrm{mM} \mathrm{CaCl}_{2} ; \mathrm{pH} 7.5$ ) in the presence or absence of compound 3c. As a control for protein stability and loss, an analogous buffer solution was added to the protein. The protein sample was excited at $280 \mathrm{~nm}$, and emission scans were collected from 300 to $425 \mathrm{~nm}$, using slit widths of $0.3 \mathrm{~nm}$ on a QM-4/ 200SE spectrofluorimeter with double excitation and emission monochromators. Between each titration, the protein/inhibitor mixture was gently stirred for $1 \mathrm{~min}$ at RT before collecting each reading. Three emission scans were collected and averaged at each concentration. The $K_{\mathrm{d}}$ was determined using the Prism software package (GraphPad V5) to fit the data to the equation $\Delta F / \Delta F_{\mathrm{Max}}$ in which $\Delta F$ is the nanometer shift for a given titration and $\Delta F_{\mathrm{Max}}$ is the maximal nanometer shift observed overall.

Small Molecule DOCKing. To DOCK the MMP-9 PEX domain inhibitors and predict the binding mode, the inhibitors were first created via the Advanced Chemistry Development Chemsketch software (ACD Laboratories, Toronto, Canada) in the MOL format. The molecules were then loaded into the program Avogadro to undergo energy minimization and were then saved as PDB format files. Once in PDB format, the molecules were individually loaded into the AutoDock Tools (The Scripps Research Institute, La Jolla, California) program and assigned charges, rotatable bonds, and a root. The molecules were saved as a pdbqt files and then used for DOCKing. The crystal structure of the PEX domain of MMP-9 was downloaded from rcsb.org (PDB code 1ITV). Chain B and all sulfate ions were deleted, followed by a brief energy minimization of the receptor via the AMBER force field. The parameters are as follows.

Steepest descent steps: 100

Steepest descent size (Angstroms): 0.01

Conjugate gradient steps: 30

Conjugate gradient step size (Ångstroms): 0.02

Force field: AMBER ff14SB (AM1-BCC)

The compounds docked underwent energy minimization via the Merck Molecular Force Field 94s (MMFF94s). DOCKing was performed via AutoDock Vina with the following parameters (untransformed coordinates of protein):

Box center $(x$ axis $)=-42.494$

Box center $(y$ axis $)=-27.748$

Box center $(z$ axis $)=5.00$

Box size $(x$ axis $)=22$

Box size $(y$ axis $)=22$

Box size $(z$ axis $)=20$

Exhaustiveness $=64$

The results were loaded in UCSF Chimera (UCSF, San Francisco, California) and saved as JPEG images.

Statistical Analysis. Data are expressed as the mean \pm standard error of triplicates. Each experiment was repeated at least three times. The Student $t$ test and analysis of variants (ANOVA) were used to assess differences with $P<0.05, * * P<0.01$, and $* * * P<0.001$.

\section{ASSOCIATED CONTENT}

\section{S Supporting Information}

The Supporting Information is available free of charge on the ACS Publications website at DOI: 10.1021/acschembio.7b00758.

Supplemental experimental procedures, figures, data, and spectra for compounds are described (PDF)

\section{AUTHOR INFORMATION}

\section{Corresponding Author}

*Phone: +1-632-632-7952. Fax: +1-631-632-5731. E-mail: nicole.sampson@stonybrook.edu.

\section{ORCID}

Vincent M. Alford: 0000-0001-7162-9955

Iwao Ojima: 0000-0002-3628-1161

Nicole S. Sampson: 0000-0002-2835-7760

\section{Author Contributions}

J.C. and N.S.S. conceived the project. V.M.A. performed and contributed to designing all protocols and experiments. I.O, A.K., X.R., K.K., and Q.G. contributed through designing and synthesizing all PEX-9 parental and derivative compounds. M.A. contributed through performing the DOCKing analysis of all derivative compounds. M.T. and M.A.S. contributed through helping design and perform STD NMR experiments in addition to kinetic experiments to measure $K_{d}$ values. V.M.A. prepared all figures and tables. All authors contributed to writing, reviewing, commenting on, and approving the final manuscript.

Notes

The authors declare no competing financial interest.

\section{ACKNOWLEDGMENTS}

This work was supported by National Institutes of Health 1R01CA166936 (to J.C. and N.S.S.), T32GM092714 (to V.M.A.) and 1R35GM119437 (to M.A.S.) and a seed grant from the Institute of Chemical Biology and Drug Discovery (to I.O.). We are grateful to Weiyi Li for all her hard work and guidance in helping use the Zeiss LSM 510 META NLO TwoPhoton Laser Scanning Confocal Microscope System at SBU's CMIC core facility. We also thank all members of the Cao and Sampson laboratory for insightful discussion and support given throughout the duration of this project.

\section{REFERENCES}

(1) Weigelt, B., Peterse, J. L., and van 't Veer, L. J. (2005) Breast cancer metastasis: markers and models. Nat. Rev. Cancer 5, 591-602.

(2) Curran, S., and Murray, G. I. (1999) Matrix metalloproteinases in tumour invasion and metastasis. J. Pathol. 189, 300-308.

(3) Curran, S., and Murray, G. I. (2000) Matrix metalloproteinases: molecular aspects of their roles in tumour invasion and metastasis. Eur. J. Cancer 36, 1621-1630.

(4) Deryugina, E. I., and Quigley, J. P. (2006) Matrix metalloproteinases and tumor metastasis. Cancer Metastasis Rev. 25, 9-34.

(5) Kessenbrock, K., Plaks, V., and Werb, Z. (2010) Matrix metalloproteinases: regulators of the tumor microenvironment. Cell 141, 52-67.

(6) Coussens, L. M., Fingleton, B., and Matrisian, L. M. (2002) Matrix metalloproteinase inhibitors and cancer: trials and tribulations. Science 295, 2387-2392.

(7) Cathcart, J., Pulkoski-Gross, A., and Cao, J. (2015) Targeting Matrix Metalloproteinases in Cancer: Bringing New Life to Old Ideas. Genes Dis. 2, 26-34.

(8) Chou, J., Chan, M. F., and Werb, Z. (2016) Metalloproteinases: a Functional Pathway for Myeloid Cells, Microbiol. Spectrum 4, DOI: 10.1128/microbiolspec.MCHD-0002-2015.

(9) Rodriguez, D., Morrison, C. J., and Overall, C. M. (2010) Matrix metalloproteinases: what do they not do? New substrates and biological roles identified by murine models and proteomics. Biochim. Biophys. Acta, Mol. Cell Res. 1803, 39-54.

(10) Fanjul-Fernandez, M., Folgueras, A. R., Cabrera, S., and LopezOtin, C. (2010) Matrix metalloproteinases: evolution, gene regulation and functional analysis in mouse models. Biochim. Biophys. Acta, Mol. Cell Res. 1803, 3-19. 
(11) Dufour, A., Sampson, N. S., Zucker, S., and Cao, J. (2008) Role of the hemopexin domain of matrix metalloproteinases in cell migration. J. Cell. Physiol. 217, 643-651.

(12) Dufour, A., Zucker, S., Sampson, N. S., Kuscu, C., and Cao, J. (2010) Role of matrix metalloproteinase-9 dimers in cell migration: design of inhibitory peptides. J. Biol. Chem. 285, 35944-35956.

(13) Cha, H., Kopetzki, E., Huber, R., Lanzendorfer, M., and Brandstetter, H. (2002) Structural basis of the adaptive molecular recognition by MMP9. J. Mol. Biol. 320, 1065-1079.

(14) Sternlicht, M. D., and Werb, Z. (2001) How matrix metalloproteinases regulate cell behavior. Annu. Rev. Cell Dev. Biol. 17, 463-516.

(15) Karadag, A., Fedarko, N. S., and Fisher, L. W. (2005) Dentin matrix protein 1 enhances invasion potential of colon cancer cells by bridging matrix metalloproteinase-9 to integrins and CD44. Cancer Res. 65, 11545-11552.

(16) Desai, B., Rogers, M. J., and Chellaiah, M. A. (2007) Mechanisms of osteopontin and CD44 as metastatic principles in prostate cancer cells. Mol. Cancer 6, 18-42.

(17) Redondo-Munoz, J., Ugarte-Berzal, E., Terol, M. J., Van den Steen, P. E., Hernandez del Cerro, M., Roderfeld, M., Roeb, E., Opdenakker, G., Garcia-Marco, J. A., and Garcia-Pardo, A. (2010) Matrix metalloproteinase-9 promotes chronic lymphocytic leukemia $b$ cell survival through its hemopexin domain. Cancer Cell 17, 160-172.

(18) Redondo-Munoz, J., Ugarte-Berzal, E., Garcia-Marco, J. A., del Cerro, M. H., Van den Steen, P. E., Opdenakker, G., Terol, M. J., and Garcia-Pardo, A. (2008) Alpha4betal integrin and 190-kDa CD44v constitute a cell surface docking complex for gelatinase B/MMP-9 in chronic leukemic but not in normal B cells. Blood 112, 169-178.

(19) Stefanidakis, M., Bjorklund, M., Ihanus, E., Gahmberg, C. G., and Koivunen, E. (2003) Identification of a negatively charged peptide motif within the catalytic domain of progelatinases that mediates binding to leukocyte beta 2 integrins. J. Biol. Chem. 278, 34674-34684. (20) Bjorklund, M., Heikkila, P., and Koivunen, E. (2004) Peptide inhibition of catalytic and noncatalytic activities of matrix metalloproteinase-9 blocks tumor cell migration and invasion. J. Biol. Chem. 279, 29589-29597.

(21) Ugarte-Berzal, E., Bailon, E., Amigo-Jimenez, I., Vituri, C. L., del Cerro, M. H., Terol, M. J., Albar, J. P., Rivas, G., Garcia-Marco, J. A., and Garcia-Pardo, A. (2012) A 17-residue sequence from the matrix metalloproteinase-9 (MMP-9) hemopexin domain binds alpha4beta1 integrin and inhibits MMP-9-induced functions in chronic lymphocytic leukemia B cells. J. Biol. Chem. 287, 27601-27613.

(22) Ugarte-Berzal, E., Bailon, E., Amigo-Jimenez, I., Albar, J. P., Garcia-Marco, J. A., and Garcia-Pardo, A. (2014) A novel CD44binding peptide from the pro-matrix metalloproteinase- 9 hemopexin domain impairs adhesion and migration of chronic lymphocytic leukemia (CLL) cells. J. Biol. Chem. 289, 15340-15349.

(23) Humphries, M. J., Komoriya, A., Akiyama, S. K., Olden, K., and Yamada, K. M. (1987) Identification of two distinct regions of the type III connecting segment of human plasma fibronectin that promote cell type-specific adhesion. J. Biol. Chem. 262, 6886-6892.

(24) Garcia-Pardo, A., Wayner, E. A., Carter, W. G., and Ferreira, O. C., Jr. (1990) Human B lymphocytes define an alternative mechanism of adhesion to fibronectin. The interaction of the alpha 4 beta 1 integrin with the LHGPEILDVPST sequence of the type III connecting segment is sufficient to promote cell attachment. J. Immunol. 144, 3361-3366.

(25) Wayner, E. A., and Kovach, N. L. (1992) Activation-dependent recognition by hematopoietic cells of the LDV sequence in the $\mathrm{V}$ region of fibronectin. J. Cell Biol. 116, 489-497.

(26) Moyano, J. V., Carnemolla, B., Dominguez-Jimenez, C., GarciaGila, M., Albar, J. P., Sanchez-Aparicio, P., Leprini, A., Querze, G., Zardi, L., and Garcia-Pardo, A. (1997) Fibronectin type III5 repeat contains a novel cell adhesion sequence, KLDAPT, which binds activated alpha4betal and alpha4beta7 integrins. J. Biol. Chem. 272, 24832-24836.

(27) Dufour, A., Sampson, N. S., Li, J., Kuscu, C., Rizzo, R. C., Deleon, J. L., Zhi, J., Jaber, N., Liu, E., Zucker, S., and Cao, J. (2011)
Small-molecule anticancer compounds selectively target the hemopexin domain of matrix metalloproteinase-9. Cancer Res. 71, 4977-4988.

(28) Birkedal-Hansen, H., Moore, W. G., Bodden, M. K., Windsor, L. J., Birkedal-Hansen, B., DeCarlo, A., and Engler, J. A. (1993) Matrix metalloproteinases: a review. Crit. Rev. Oral Biol. Med. 4, 197-250.

(29) Nagase, H., Suzuki, K., Morodomi, T., Enghild, J. J., and Salvesen, G. (1992) Activation mechanisms of the precursors of matrix metalloproteinases 1, 2 and 3. Matrix Suppl. 1, 237-244.

(30) Galazka, G., Windsor, L. J., Birkedal-Hansen, H., and Engler, J. A. (1996) APMA (4-aminophenylmercuric acetate) activation of stromelysin-1 involves protein interactions in addition to those with cysteine-75 in the propeptide. Biochemistry 35, 11221-11227.

(31) Belmokhtar, C. A., Hillion, J., and Segal-Bendirdjian, E. (2001) Staurosporine induces apoptosis through both caspase-dependent and caspase-independent mechanisms. Oncogene 20, 3354-3362.

(32) Lu, P., Takai, K., Weaver, V. M., and Werb, Z. (2011) Extracellular matrix degradation and remodeling in development and disease. Cold Spring Harbor Perspect. Biol. 3, a005058.

(33) Bonnans, C., Chou, J., and Werb, Z. (2014) Remodelling the extracellular matrix in development and disease. Nat. Rev. Mol. Cell Biol. 15, 786-801.

(34) Radisky, E. S., Raeeszadeh-Sarmazdeh, M., and Radisky, D. C. (2017) Therapeutic Potential of Matrix Metalloproteinase Inhibition in Breast Cancer. J. Cell. Biochem. 118, 3531-3548.

(35) Wojtowicz-Praga, S. M., Dickson, R. B., and Hawkins, M. J. (1997) Matrix metalloproteinase inhibitors. Invest. New Drugs 15, 6175.

(36) Palacios, E. H., and Weiss, A. (2004) Function of the Src-family kinases, Lck and Fyn, in T-cell development and activation. Oncogene 23, 7990-8000.

(37) Hsia, D. A., Lim, S. T., Bernard-Trifilo, J. A., Mitra, S. K., Tanaka, S., den Hertog, J., Streblow, D. N., Ilic, D., Ginsberg, M. H., and Schlaepfer, D. D. (2005) Integrin alpha4betal promotes focal adhesion kinase-independent cell motility via alpha4 cytoplasmic domain-specific activation of c-Src. Mol. Cell. Biol. 25, 9700-9712.

(38) Li, L., Okura, M., and Imamoto, A. (2002) Focal adhesions require catalytic activity of Src family kinases to mediate integrinmatrix adhesion. Mol. Cell. Biol. 22, 1203-1217.

(39) Zhao, X. K., Cheng, Y., Liang Cheng, M., Yu, L., Mu, M., Li, H., Liu, Y., Zhang, B., Yao, Y., Guo, H., Wang, R., and Zhang, Q. (2016) Focal Adhesion Kinase Regulates Fibroblast Migration via Integrin beta-1 and Plays a Central Role in Fibrosis. Sci. Rep. 6, 19276-19288.

(40) Westhoff, M. A., Serrels, B., Fincham, V. J., Frame, M. C., and Carragher, N. O. (2004) SRC-mediated phosphorylation of focal adhesion kinase couples actin and adhesion dynamics to survival signaling. Mol. Cell. Biol. 24, 8113-8133.

(41) Brown, M. C., Cary, L. A., Jamieson, J. S., Cooper, J. A., and Turner, C. E. (2005) Src and FAK kinases cooperate to phosphorylate paxillin kinase linker, stimulate its focal adhesion localization, and regulate cell spreading and protrusiveness. Mol. Biol. Cell 16, 43164328.

(42) Mitra, S. K., and Schlaepfer, D. D. (2006) Integrin-regulated FAK-Src signaling in normal and cancer cells. Curr. Opin. Cell Biol. 18, $516-523$.

(43) Wu, L., Bernard-Trifilo, J. A., Lim, Y., Lim, S. T., Mitra, S. K., Uryu, S., Chen, M., Pallen, C. J., Cheung, N. K., Mikolon, D., Mielgo, A., Stupack, D. G., and Schlaepfer, D. D. (2008) Distinct FAK-Src activation events promote alphasbetal and alpha4betal integrinstimulated neuroblastoma cell motility. Oncogene 27, 1439-1448.

(44) Sen, B., and Johnson, F. M. (2011) Regulation of SRC family kinases in human cancers. J. Signal Transduction 2011, 865819865833.

(45) Osherov, N., and Levitzki, A. (1994) Epidermal-growth-factordependent activation of the src-family kinases. Eur. J. Biochem. 225, $1047-1053$.

(46) Mao, W., Irby, R., Coppola, D., Fu, L., Wloch, M., Turner, J., Yu, H., Garcia, R., Jove, R., and Yeatman, T. J. (1997) Activation of c-Src by receptor tyrosine kinases in human colon cancer cells with high metastatic potential. Oncogene 15, 3083-3090. 
(47) Vandooren, J., Born, B., Solomonov, I., Zajac, E., Saldova, R., Senske, M., Ugarte-Berzal, E., Martens, E., Van den Steen, P. E., Van Damme, J., Garcia-Pardo, A., Froeyen, M., Deryugina, E. I., Quigley, J. P., Moestrup, S. K., Rudd, P. M., Sagi, I., and Opdenakker, G. (2015) Circular trimers of gelatinase $\mathrm{B} /$ matrix metalloproteinase- 9 constitute a distinct population of functional enzyme molecules differentially regulated by tissue inhibitor of metalloproteinases-1. Biochem. J. 465, 259-270.

(48) Yu, X., Miyamoto, S., and Mekada, E. (2000) Integrin alpha 2 beta 1-dependent EGF receptor activation at cell-cell contact sites. J. Cell Sci. 113 (12), 2139-2147.

(49) Friedl, P., and Wolf, K. (2003) Tumour-cell invasion and migration: diversity and escape mechanisms. Nat. Rev. Cancer 3, 362374.

(50) Alford, V. M., Roth, E., Zhang, Q., and Cao, J. (2016) A Novel Collagen Dot Assay for Monitoring Cancer Cell Migration. Methods Mol. Biol. 1406, 181-187.

(51) Knight, C. G., Willenbrock, F., and Murphy, G. (1992) A novel coumarin-labelled peptide for sensitive continuous assays of the matrix metalloproteinases. FEBS Lett. 296, 263-266.

(52) Mosmann, T. (1983) Rapid colorimetric assay for cellular growth and survival: application to proliferation and cytotoxicity assays. J. Immunol. Methods 65, 55-63.

(53) Deryugina, E. I., and Quigley, J. P. (2008) Chick embryo chorioallantoic membrane model systems to study and visualize human tumor cell metastasis. Histochem. Cell Biol. 130, 1119-1130.

(54) Ribatti, D., Nico, B., Vacca, A., Roncali, L., Burri, P. H., and Djonov, V. (2001) Chorioallantoic membrane capillary bed: a useful target for studying angiogenesis and anti-angiogenesis in vivo. Anat. Rec. 264, 317-324.

(55) Ribatti, D., Nico, B., Vacca, A., and Presta, M. (2006) The gelatin sponge-chorioallantoic membrane assay. Nat. Protoc. 1, 85-91. (56) LeBleu, V. S., Macdonald, B., and Kalluri, R. (2007) Structure and function of basement membranes. Exp. Biol. Med. (London, U. K.) 232, 1121-1129.

(57) Imai, K., and Okada, Y. (2008) Purification of matrix metalloproteinases by column chromatography. Nat. Protoc. 3, $1111-1124$ 